\title{
Le SEPTENTRION (1811-1866)
}

\section{Prosopografie van een Gentse vrijmetselaarsloge}

\author{
Bruno Frank Van Verdeghem
}

\section{Inleiding ${ }^{1}$}

“Ne touchez pas à la Franc-Maçonnerie! C'est un sujet 'tabou'. Même si vous le traitez d'une manière objective, vous finirez par mécontenter tout aussi bien les Francs-Maçons que les Catholiques, car on ne peut parler de la Franc-Maçonnerie sans parler de l'Eglise. Ne soulevez pas cette question!" Deze waarschuwing kreeg Gérard Serbanesco mee van zijn omgeving toen hij zich voornam de geschiedenis van de universele vrijmetselarij te schrijven. ${ }^{2}$ Ondanks dit ontradend advies heb ik me toch aan het onderwerp gewaagd, en heb ik ervoor gekozen om, in het kader van mijn masterscriptie, Le Septentrion onder de loep te nemen, de oudste nog bestaande vrijmetselaarsloge van Gent. Meer bepaald spitste mijn onderzoek zich toe op de periode gaande van de oprichting van Le Septentrion op 2 april 1811 tot wanneer op 1 maart 1866, als gevolg van onenigheid binnen deze werkplaats, de (ook nog steeds bestaande) loge La Liberté ontstaat, als gevolg van een afscheiding van Le Septentrion.

In dit artikel belicht ik de vrijmetselaars die samen Le Septentrion uitmaken. De leden zijn immers in grote mate bepalend voor het profiel van de werkplaats en voor de activiteiten die zij ontwikkelt. In eerste instantie heb ik gepoogd het ledenbestand zo goed mogelijk te reconstrueren door de enkele ledenlijsten die ik in de archieven heb aangetroffen in een databank over te brengen. Maar omdat deze ledenlijsten telkens momentopnames zijn (d.i. een lijst van de leden op een welbepaald tijdstip, en dus geen continue register met alle opeenvolgende namen van diegenen die tot de werkplaats toetreden), moeten deze overzichten worden aangevuld met gegevens uit verslagboeken van de zittingen (de zgn. Livres d'Architecture)

1 De auteur dankt zijn promotor prof. dr. René Vermeir voor alle raad en hulp bij de totstandkoming van de masterscriptie waarop dit artikel gebaseerd is.

2 Gérard Serbanesco, Histoire de la Franc-Maçonnerie universelle: son rituel, son symbolisme (Paris: Demange, 1966), 25-6. 
en uit een veelheid van andere bronnen, zowel van maçonnieke als niet-maçonnieke aard.

Maar een lijst van leden zegt maar weinig als de economische, sociale en maatschappelijke positie van de leden die erop figureren, niet gekend is. Het onderzoek naar de leden start met een analyse van een reeks relevante levensdata. Waar en wanneer zijn de vrijmetselaars geboren? Woonden ze allemaal in het Gentse? Wanneer zijn ze overleden? Hoe oud werden ze? Aansluitend stel ik de vraag naar hun intredeleeftijd in Le Septentrion. En voorts: lid zijn is één zaak, de vergaderingen regelmatig bijwonen (de "aanwezigheid") is een andere. De voertaal in Le Septentrion was (en is) in principe het Frans. Maar waren alle leden effectief Franstalig? En hoe stond de werkplaats tegenover het Nederlands? Ook de (eventuele) religieuze overtuiging van de vrijmetselaars wordt geanalyseerd. Wijzigde de houding t.a.v. het katholicisme na het episcopale verbod van 1838? Vervolgens worden het professionele en sociaal-economische profiel van de vrijmetselaars onderzocht. Tot welke beroepsgroepen behoorden ze? Waren er ondernemers onder de leden van Le Septentrion, en zo ja, behoorden die tot de Kamer van Koophandel of tot de Cercle Commercial et Industriel? Nauw verbonden met de sociaal-economische achtergrond van de leden, is de vraag wie van hen binnen het cijnskiesrecht stemgerechtigd was. En wie van hen was rijk genoeg om verkiesbaar te zijn voor de Senaat?

Een aantal vrijmetselaars was politiek actief. Wat was hun eventuele rol in het kader van de oprichting en de ontwikkeling van de Liberale Partij? En welke politieke mandaten bekleedden zij? De leden van de werkplaats waren ook goed ingebed in het sociale weefsel en het verenigingsleven van de stad. Waren zij actief in de Société Huet, La Concorde, het Willemsfonds of het Van Crombrugghe's Genootschap? Gebruik makend van het onderzoek van Guy Schrans over het Gentse logeleven in de 18de eeuw, zal waar mogelijk ook nagegaan worden wie van de leden van Le Septentrion persoonlijke of familiale banden hadden met de Gentse vrijmetselaarsloges uit de Oostenrijkse en Franse Tijd. Op die manier kan misschien een zekere mate van continuïteit worden blootgelegd.

De zoektocht naar antwoorden op al deze vragen heeft toegelaten de contouren te schetsen van de leden van Le Septentrion in de periode 1811-1866. Maar omdat deze vrijmetselaars uiteraard niet geïsoleerd leefden, maar werkten en actief waren binnen een specifieke sociale, politieke en economische situatie, die mede hun denken en handelen bepaalde, wordt in de volgende paragraaf eerst kort ingegaan op de historische context waarbinnen Le Septentrion zich heeft ontwikkeld. 


\section{Situering van de historische context}

De geschiedenis van de eerste 55 jaar van de Gentse loge Le Septentrion kan niet los gezien worden van de historische context. In die periode veranderde het Gentse grondgebied drie keer van overheerser. Tot de val van Napoleon in 1814 ressorteerde Gent onder het Franse keizerrijk. Als gevolg van beslissingen genomen op het Congres van Wenen maakte Gent vervolgens deel uit van het Verenigd Koninkrijk der Nederlanden. Sinds de omwenteling van 1830 vormen de Zuidelijke Nederlanden het koninkrijk België. Ik ga nu dieper in op de politieke ontwikkelingen die de vrijmetselaars in het algemeen en de leden van Le Septentrion in het bijzonder sensibiliseren.

Gent werd op economisch vlak het 'Vlaamse Manchester' genoemd omwille van zijn welvarende textielindustrie. Politiek ontwikkelde de burgerij zich ten nadele van adel en geestelijkheid. Internationaal waren de politieke dagen van Napoleon geteld. Het Verenigd Koninkrijk der Nederlanden was economisch succesvol. In die vijftien jaar stimuleerde Willem I verder de Gentse textielindustrie. Gent kreeg in 1817 een rijksuniversiteit en het kanaal Gent-Terneuzen werd gegraven. In die periode werden ook de grondslagen van een lekenstaat gelegd, die onttrokken zou zijn aan de controle van de clerus. De leden van de Gentse loges waren dit beleid genegen en het Nederlands regime was de werkplaatsen gunstig gezind. ${ }^{3}$ De Hollandse dynastie gebruikte de loges als een middel voor de eenheid tussen Noord en Zuid. ${ }^{4}$ De sympathie van het Nederlandse vorstenhuis verklaart deels de orangistische voorkeuren van de vrijmetselaars. Ook de afzetmarkten voor textiel in de $\mathrm{Ne}$ derlandse kolonies liggen mede aan de basis van het orangisme van de Gentse burgerij. 5

De leden van Le Septentrion legden zich niet neer bij de nieuwe staat België. Vrijmetselaars waren betrokken bij de contrarevolutionaire aanvallen. ${ }^{6}$ Op politiek vlak diende Le Septentrion het meest het orangisme. Zelfs vanuit Lille, toen Metdepenningen en zijn medestanders daar tijdelijk verbleven, ageerde Le Septentrion als 'comité militant central'. De leden van de Gentse loges vormden een gedisciplineerd electoraal korps. Zij waren lid van La Société des Amis de l'Ordre et du Re-

3 Jeffrey Tyssens, "Van Wijsheid met Vreugd gepaard," in Van Wijheid met Vreugd gepaard: Twee eeuwen vrijmetselarij in Gent en Antwerpen, eds. Tyssens Jeffrey (Brussel: Marot, 2003), 17.

4 C. Parmentier, Historique de la Francmaçonnerie gantoise (Gent: onuitgegeven publicatie, 1924), 23-6, zoals geciteerd in Tyssens, Van Wijsheid met Vreugd gepaard. Telkens als ik dit boek vermeld, gaat het om een verwijzing van Jeffrey Tyssens naar deze onuitgegeven publicatie in zijn werk Van wijsheid met vreugd gepaard.

5 Joël Arvelle, Histoire de la franc-maçonnerie belge (Braine-l'Alleud: Collet, 1995), 42-3.

6 Els Witte, Het verloren koninkrijk: het harde verzet van de Belgische orangisten tegen de revolutie (1828-1850) (Antwerpen: Bezige Bij, 2014), 208-12. 
pos Public, de kiesvereniging van de Gentse orangisten. ${ }^{7}$ De leden van Le Septentrion voerden dus in het eerste decennium van de onafhankelijkheid een antiBelgische politiek. Dit verzet nam grote proporties aan en de orangisten behielden een duidelijke meerderheid in de gemeenteraad in de periode 1831-1839. Pas na de ondertekening van het Verdrag der XXIV Artikelen op 19 april 1839, waarbij koning Willem I België erkende, ebde de contrarevolutionaire gedachte weg. ${ }^{8}$ De orangisten gingen de rangen van de liberaal Belgischgezinden versterken. Met hen hadden ze twee belangrijke punten gemeen: het economisch liberalisme en het antiklerikalisme. ${ }^{9}$

De voormelde aansluiting bij de liberalen legde de kiem voor een confessionele strijd, die het denken en handelen van de leden van Le Septentrion in de resterende periode (1840-1866) zou karakteriseren. In de periode 1840-1846 kende het unionisme zijn verval. De eerste Organieke Wet op het lager onderwijs van 23 september 1842 erkende dat godsdienst en moraal onafscheidelijk verbonden waren. Ze stond de feitelijke supervisie van de geestelijkheid toe en steunde het vrije onderwijs financieel, omdat elke gemeente een katholieke school mocht aannemen. ${ }^{10}$ Het regeringsontwerp op het middelbaar onderwijs was liberaal georiënteerd en gaf, volgens de katholieken, te veel macht aan de staat. ${ }^{11}$ Op 14 juni 1846 vergadert in Brussel het Liberaal Congres. Dit zou leiden tot de oprichting van de Liberale Partij. ${ }^{12}$ Een volgende confrontatie hield verband met de Wet op de liefdadige stichtingen, smalend 'de kloosterwet' of 'la loi sur les couvents' genoemd. Dit zou de kloosters verrijken en hun invloed doen toenemen. ${ }^{13}$

$\mathrm{Na} 1857$ groeien de invloed van de progressisten in de liberale partij en deze van de ultramontaanse katholieken binnen de katholieke partij. De loges telden progressisten onder hun leden en gingen nu niet enkel strijd voeren tegen het klerikalisme maar ook tegen de godsdienst zelf. Toen ontstond op 26 december 1864 uit de Libre Pensée de 'Ligue de l'Enseignement'. De Ligue kwam niet enkel op voor

Anaïs Maes, Flamands? Wallons? Belges et Francs-Maçons! La Franc-Maçonnerie et la construction d'identités nationales en Belgique au long Xixe siecle (Brussel: ASP,120).

$8 \quad$ Witte, Het verloren koninkrijk, 225, 281 en 287.

9 Gita Deneckere, Tom De Paepe, Bruno De Wever en Guy Vanthemsche, Een geschiedenis van België. Derde herziene druk (Gent: Academia Press, 2014), 94-97.

10 Els Witte, Jan Craeybeckx en Alain Meynen, Politieke geschiedenis van België Van 1830 tot heden, zesde herziene uitgave (Antwerpen: Standaard, 1997), 38-40; Deneckere et al., Een geschiedenis van België, 108.

11 Kathleen Devolder, Gij die door 't volk gekozen zijt ... De Gentse gemeenteraad en haar leden 1830-1914 (Gent: Maatschappij voor geschiedenis en oudheidkunde, 1994), 342.

12 Theo Luykx en Marc Platel, Politieke Geschiedenis Van België, vijfde bijgewerkte uitgave aangevuld door Marc Platel (Antwerpen: Kluwer, 1985), 94; Witte, Craeybeckx en Meynen, Politieke geschiedenis van België, 54.

13 Deneckere et al., Een geschiedenis van België, 109. 
de verdediging van het rijksonderwijs, maar wilde een volledige laïcisering doorvoeren. ${ }^{14}$

Op maçonniek vlak zijn drie gebeurtenissen belangrijk voor deze studie over Le Septentrion: de reden waarom Le Septentrion werd opgericht, de episcopale veroordeling van de vrijmetselarij op 28 december 1837 (pas kenbaar gemaakt in 1838) en de schrapping in 1854 van het verbod op religieuze en politieke discussies in de loges door het Grootoosten van België. Kort licht ik de drie gebeurtenissen toe. Toen Le Septentrion opgericht werd, bestonden in Gent reeds twee werkplaatsen: Les Vrais Amis en La Félicité Bienfaisante. Le Septentrion ontstond uit een eerdere mislukte poging om de werkplaats La Constante Union te reactiveren. Die mislukking was te wijten aan het verzet van beide bestaande werkplaatsen, omdat zij niet wilden dat 'membres peu recommandables' een werkplaats zouden oprichten. De oprichting van Le Septentrion gebeurde via een omweg. Zeven leden van La Constante Union affilieerden bij La Félicité Bienfaisante en gaven na een week hun ontslag. ${ }^{15}$ In tegenstelling tot wat in de bestaande literatuur over de Gentse vrijmetselarij algemeen wordt aangenomen, werd Le Septentrion dus opgericht als een werkplaats voor leden met minder vermogen en minder sociaal aanzien. ${ }^{16}$

Paus Clemens XII had op 28 april 1738 de vrijmetselarij veroordeeld. De Geheime Raad gaf er geen gevolg aan. Zijn bul kreeg dus geen "placet". ${ }^{17}$ Tot 1838 konden katholieken zonder probleem lid zijn van een vrijmetselaarsloge. Een schrijven van E. Des Essarts, één van de dignitarissen van de loge Amis Philantropes, aan Goswin baron de Stassart, voorzitter van de senaat, gouverneur van Brabant en grootmeester van het Grootoosten van België, uit 1836 toont aan dat de aanwezigheid van katholieken in loges de vrijmetselarij zelfs verhinderde om de antiklerikale tour op te gaan. Als een voorbode verscheen volgende zin in het katholiek dagblad Le Conservateur belge in augustus 1837: "Les loges maçonniques renferment les derniers restes antichrétiens de la république, de l'Empire et de la

14 Jacques Lory, Libéralisme et instruction primaire: 1842-1879: Introduction à l'étude de la lutte scolaire en Belgique (Louvain: UCL. Bibliothèque de l'université, 1979), 303-23. De Libre Pensée ontstaat op 19 januari 1863. De leden van deze vereniging komen uit de middenklasse en de kleine burgerij. Zij evolueert van een vereniging die burgerlijke uitvaarten organiseert naar een vereniging die de nadruk legt op het zelf bewustzijn en op opleiding. De leden pogen fouten, vooroordelen en onwetendheid uit te schakelen. Dit impliceert onder andere vrijheid van onderwijs.

15 Eenmaal ingewijd kan een vrijmetselaar van loge wisselen. Dit noemt men affiliatie (membres affiliés).

16 Jeffrey Tyssens, "Vrijmetselarij in Gent, 1763-1940," In Huldeboek Prof. Dr. Marcel Bots: een bundel historische en wijsgerige opstellen, eds. Luc Pareyn, Adriaan Verhulst en Marcel Bots (Gent: Liberaal Archief, 1995), 42; De Schampheleire, Witte en Borné, Bibliografische bijdrage tot de geschiedenis der Belgische vrijmetselarij (Leuven: Aurelia, 1973), 76: “... een aantal vrijmetselaars, geenszins afkomstig uit de hogere sociale lagen, ...”.

17 Pierre Cockshaw, "Observations sur les deux premières bulles de condamnation (1738 et 1751) et leur réception dans nos régions," in Visages de la Franc-Maçonnerie belge du xviiie au xxe siècle, eds. Hasquin Hervé (Brussel: Editions ULB, 1983), 74, 76 en 81. 
Restauration." ${ }^{18}$ De oprichting van de niet-orangistische loge te Gent La Fidélité in aanwezigheid van de Stassart leidde tot de episcopale veroordeling van de vrijmetselarij. ${ }^{19}$ Het verschijnen van de bisschoppelijke omzendbrief op 28 december 1837 verbrak het katholieke stilzwijgen over de vrijmetselarij. De voorafgaande pauselijke veroordelingen maakten het voor gelovigen ten strengste verboden deel uit te maken van de vrijmetselarij. Verschillende redenen liggen aan de basis. Vooreerst is er de druk van de pauselijke veroordelingen uit de 18de eeuw, de hulp van de vrijmetselarij aan het lekenonderwijs sinds Willem II en de Stichting van de ULB (Université libre de Bruxelles). De verschijning van nieuwe loges was een probleem voor de clerus, zeker in Gent. Koning Leopold I was maçon en beschermde de vrijmetselarij. Hij pushte zijn vertrouweling, de Stassart, om Grootmeester van het Grootoosten van België te worden in 1835. Aansluitend richtte deze in Gent de loge La Fidélité op tegen de orangistische loges. De klerikalen dachten dat de oprichting van dergelijke loges de Unionistische partij zou verdelen in katholieken en liberalen. Bovendien verhinderde haar orangisme Le Septentrion om effectieve politieke invloed uit te oefenen. Een Belgisch gezinde loge zou op termijn een machtsfactor van belang zijn. De echte reden was in de eerste plaats politiek geïnspireerd nl. het katholicisme opleggen als staatsgodsdienst. ${ }^{20}$ De klerikalen kregen bovendien schrik dat er steeds meer loges bijkwamen, zeker militaire werkplaatsen, waar officieren een nefaste invloed uitoefenden. ${ }^{21}$ Militaire loges waren nuttig voor Koning Leopold I en voor de Stassart. Zij garandeerden het loyalisme van het leger. Monseigneur Van Bommel, bisschop van Luik, zag in het militaire leven een instrument van ontchristening ('déchristianisation'). De officieren-vrijmetselaar zouden de niet religieuze gezindheid van de soldaten aanwakkeren. In het leger zouden de jonge mannen ook het geloof van hun ouders verliezen. ${ }^{22}$ De omzendbrief leidde niet tot het verhoopte succes. Slechts enkelen haakten af. De vrijmetselaars onderlijnden dat ze zeker niet antireligieus waren. ${ }^{23}$ Het unionisme liep op zijn einde. Het herderlijk schrijven was eerder de katalysator van een tendens die er zat aan te komen, en zeker niet de motor. ${ }^{24}$

18 John Bartier en Guy Gambier, "La condamnation de la franc-maçonnerie par les évêques belges en 1837," in Laïité Et Franc-Maçonnerie, eds. Bartier John en Gambier Guy (Bruxelles: ULB, 1981), 226-27.

19 Alois Simon, L'hypothèse libérale en Belgique: documents inédits 1839-1907 (Wetteren: Scaldis, 1956), 154; John Bartier en Guy Gambier, Laïcité et franc-maçonnerie, 2e tirage (Brussel: ULB, 1982),227; Joël Arvelle, Histoire de la franc-maçonnerie belge (Braine-l'Alleud: Collet, 1995), 69.

20 Bartier en Gambier, “La condamnation de la franc-maçonnerie ...”, 228 en 230. (Schrijven van vrijmetselaar Braes uit Namen aan de Stassart. "De katholieken willen een theocratie. De maatregelen tegen de vrijmetselarij zijn ingegeven door een dorst naar macht.")

21 Arvelle, Histoire de la franc-maçonnerie belge, 68-9.

22 Bartier en Gambier, "La condamnation de la franc-maçonnerie ?”, 229.

23 Leton, Liège, loges et chapitres, 156-159: Maes Anais, ?, 130.

24 Maes Anais, ..., 132. 
Toen tenslotte het Grootoosten van België het fameuze artikel 135 uit haar statuten liet schrappen, werd het werkplaatsen toegestaan politiek te bedrijven. Het ging eerder om een symbolische daad. ${ }^{25}$ Le Septentrion was aangesloten bij het Grootoosten van Nederland. Sinds 1830 waren meerdere leden met orangistisch signatuur politiek actief. $\mathrm{Na} 1854$ verschijnen toch meer politieke discussies in de primaire bronnen.

\section{De bronnen}

In dit deel geef ik een summier overzicht van de bronnen en van de literatuur die ik gebruikt heb om het repertorium van leden, ereleden en geaffilieerden samen te stellen. In dit kader behoren de ledenlijsten, de verslagboeken, waarin de schetsen van elke zitting opgetekend werden, de beslissingen van de Middenkamer en van de Commissie van Officieren-Dignitarissen tot de belangrijkste bronnen. Ik bespreek deze primaire bronnen naar belangrijkheid.

Onder de primaire bronnen zijn de registers met de verslagen van de zittingen, ook 'livres d'esquisse' of 'livres d'architecture' genoemd, van bijzonder groot belang. De verslagen geven het leven weer van de werkplaats en worden bijna altijd goedgekeurd met unanimiteit. ${ }^{26}$ Alle belangrijke beslissingen worden op zitting meegedeeld en heikele punten worden bediscussieerd. De namen van de ingewijde profanen, de geaffilieerde vrijmetselaars, de ontslagen, geschrapte en overleden vrijmetselaars zijn geregistreerd. Soms worden ook de personalia van de vrijmetselaars vermeld zoals een geboortedatum of een beroep. De schetsboeken zijn chronologisch verspreid over negen verschillende delen, die de periode 1811 tot 1868 bestrijken. ${ }^{27} \mathrm{Zij}$ bevatten de schetsen van de zittingen in de eerste graad (de leerlingengraad), de zittingen in de tweede graad (de gezellengraad) en de derde graad (de meestergraad) tot 1846 . Vanaf 1846 zijn de zittingen in de gezellengraad geacteerd in twee aparte schetsboeken. ${ }^{28}$ De zittingen in de meestergraad zijn in één apart

25 Vergauwen, Maçonnieke chansons, 47, 51.

26 2.A.10/(1.0629), Livre d'architecture (1834-1837), 1837-01-03-106. Pas in 1837 wordt voor het eerst een verslag niet met unanimiteit goedgekeurd. De vrijmetselaars Ottevaere, De Nobele en Lateur gaan niet akkoord.

27 2.A.10/(1.0626), Livre d'architecture (1811-1815); 2.A.10/(1.0627), Livre d'architecture (1816-1828); 2.A.10/(1.0628), Livre d'architecture (1829-1834); 2.A.10/(1.0629), Livre d'architecture (1834-1837); 2.A.10/(1.0632), Livre d'architecture (1837-1843); 2.A.10/(1.0633), Livre d'architecture (Premier grade) (1844-1853); 2.A.10/(1.0638), Livre d'architecture (l degré) (1854-1863); 2.A.10/(1.0640), Livre d'architecture (1 degré) (1863-1868) en Liberaal Archief, Gent, Verslagboek (eerste graad) (1853-1854).

28 2.A.10/(1.0635), Livre d'architecture (Il degré) (1846-1862); 2.A.10/(1.0637), Livre d'architecture (degré?) (1849-1854). Als na de notering in de voetnoten een plusteken staat, wijst dit op een corresponderend verslag in de tweede of derde graad. Bijvoorbeeld: 1846-04-21-105+. 
schetsboek opgenomen voor de periode $1846-1862 .{ }^{29}$ De verslagen van de Conseil d'Administration (COA) bevatten naast beleidsbeslissingen, ook voorbereidingen van banketten en feesten, discussies over het gebouw en veel financiële informatie, ook besprekingen van delicate inwijdingen. ${ }^{30} \mathrm{Zij}$ zijn in één boek bewaard voor de periode 1835-1873. ${ }^{31}$ De schetsboeken en het boek met de COA-verslagen bevinden zich allemaal in het Cedom-Madoc te Brussel, behalve het schetsboek van de periode 1853-1855 dat zich in het Liberaal Archief bevindt.

Verschillende documenten hebben betrekking op de leden van de werkplaats. Zo zijn er in eerste instantie drie mappen met losse documenten die verband houden met de selectie en initiatie van nieuwe vrijmetselaars en met hun loonsverhoging. ${ }^{32}$ Ook een aantal schriftelijke antwoorden op vragen naar aanleiding van hun vraag tot opname in de werkplaats vindt men in die mappen. Daarnaast bestaan er verschillende ledenlijsten en twee registers met personalia. Het 'Registre matricule' omvat de periode 1815-1923 en de 'Table générale' de periode 1811 tot 1822. De voormelde drie mappen en de beide registers bevinden zich eveneens in het Cedom-Madoc in Brussel. ${ }^{33} \mathrm{Zij}$ vormen een welkome aanvulling bij de ledenlijsten. De Bibliothèque Nationale in Parijs is in het bezit van een ledenlijst gecertifieerd op 2 april 1811 en van lijsten opgesteld op 2 april 1811, 23 mei 1811 en 1 juli 1813. ${ }^{34}$ Bovendien bevinden zich in het archief van de loge L'Aurore, dat bewaard

\section{A.10/(1.0636), Livre d'architecture (III degré) (1846-1856).}

30 La Commission d'Administration, COA genoemd. Haar werking wordt omschreven in hoofdstuk XVI van het reglement van 1818 en omvat de artikelen 94 tot 104 . Haar werking wordt genotuleerd.

31 2.A.10/(1.0631), Registre des délibérations du Conseil d'Administration (1835-1873).

32 Elke nieuw ingewijde vrijmetselaar start in de leerlingengraad. Na verloop van tijd wordt hij bevorderd tot gezel en nadien tot meester. Die bevordering noemen de vrijmetselaars 'loonsverhogingen'.

33 2.A.10/(1.0656), Correspondances diverses. Documents (dont certains en néerlandais) sur des initiations et augmentations de salaire (1833-1853); 2.A, 10/(1.0659), Documents relatifs à des initiations et à des augmentations de salaire (1853-1860); 2.A.10/(1.0678), Documents sur initiations et augmentations de salaire (1860-1866); 2.A.10/(1.0676), Registre matricule (1815-1923); 2.A.10/(1.0669), Table générale de tous les membres de la loge contenant leurs noms, prénoms, âges et qualités ainsi que la date de leurs réceptions aux trois Grades Symboliques (1822).

34 Hugo De Schampheleire, Els Witte en F. Borné,"Vrijmetselaars te Gent tijdens het Empire en de Hollandse periode (1804-1824)," Handelingen der Maatschappij voor Geschiedenis en Oudheidkunde te Gent (1971): 81 en voetnoot 13; Tableau nominatif des membres composant la $\mathrm{R}$ (espectable) $\mathrm{L}$ (oge) sous le titre distinctif du Septentrion à l'Orient de Gand, certifié par nous, Officiers de la R(espectable) L(oge) de la Félicité Bienfaisante à l'Orient de Gand, le 2 me jour du 2 me mois de l'an de la V(raie) L(umière) 5811 (B.N.P., F.M. 2/ 553, L., f $\mathrm{f}^{\circ}$ 35); Tableau des membres composant la R(espectable) L(oge) de St. Jean sous le titre distinctif du Septentrion à l'Orient de Gand (Escaut) à l'époque du $2^{\mathrm{e}}$ jour du $2^{\mathrm{e}}$ mois de l'an de la V(raie) L(umière) 5811 (B.N.P., F.M. 2/553, L., f 36, 37, 38); Tableau des Off(iciers) Digni(taires) et des F(rères) qui composent la $\mathrm{R}$ (espectable) L(oge) de St. Jean sous le titre distinctif du Septentrion à l'Orient de Gand (Escaut) à l'époque de l'an de la V(raie) L(umière) 5813 du 1er jour du $5^{\mathrm{e}}$ mois (B.N.P., F.M. 2/553, L., f $\mathrm{f}^{\circ}$ 39-44); Liste des Off(iciers) Dign(itaires) et des F(rères) qui composent la $\mathrm{R}$ (espectable) L(oge) de St. Jean, sous le titre distinctif du Septentrion à l'O(rient) de Gand, (régulièrement constituée par la G(rand) O(rient) de France le $4^{\mathrm{e}}$ jour du $8^{\mathrm{e}}$ mois de l'an de la V(raie) L(umière) 5812) à l'époque du le jour du $5^{\mathrm{e}}$ mois de l'an de la $\mathrm{V}($ raie) L(umière) 5813 Gand, les Trois L(oges),1813, 26 cm., 8 (B.N.P., FM2 553, doss. Loge Septentrion, fos, 404). 
wordt in het stadsarchief van Oudenaarde, nog vier ledenlijsten van Le Septentrion namelijk op datum van 2 april 1811, 4 oktober 1812, 2 januari 1819 en 8 maart 1823. ${ }^{35} \mathrm{Het}$ archief van het bisdom Brugge beschikt over de ledenlijst van 8 maart $1823 .{ }^{36}$ Het archief van Le Septentrion beschikt zelf nog over een kopij van een ledenlijst en een lijst van de Commissie van Officieren-Dignitarissen ${ }^{37}$ uit 1812.38 Voor de maçonnieke jaren 5853-5858 beschikt het Cultureel Maçonniek Centrum 'Prins Frederik' in Den Haag over ledenlijsten. ${ }^{39}$ Voor het jaar 1866 is er een gedeeltelijke ledenlijst beschikbaar in die zin dat de namen bekend zijn van de vrijmetselaars die Le Septentrion verlaten hebben voor La Liberté. Hiervoor verwijs ik naar de databank van René Vermeir, die hij opgemaakt heeft naar aanleiding van de studie van de werkplaats La Liberté. De aanwezigheid van de leden op de zittingen in de periode 1853-1862 werd eveneens in een boek opgetekend. ${ }^{40}$ Een bijkomend hulpmiddel is het tableau van de necrologie (de 'stèle funéraire' genoemd), dat in de gebouwen van Le Septentrion ophangt. Dit vermeldt de naam en het jaar van overlijden van de vrijmetselaars die in hun hoedanigheid van vrijmetselaar overleden zijn. Vrijmetselaars kunnen wel in de ledenlijsten voorkomen maar niet op de stèle funéraire. Zij hebben tijdens het leven de vrijmetselarij de rug toegekeerd. Of zij desaffilieerden en trokken dus naar andere werkplaatsen. Mogelijks betaalden zij net voor hun overlijden hun contributie niet meer.

35 Tableau des Membres composant la L(oge) de St. Jean sous le titre distinctif du Septentrion à l'O(rient) de Gand à l'époque du 2 me jour du 2 me mois de l'an de la V(raie) L(umière) 5811 , jour de la demande en constitution (SAO); Tableau des $\mathrm{F}$ (rères) composant la $\mathrm{L}(\mathrm{oge})$ de St. Jean sous le titre distinctif du Septentrion à l'O(rient) de Gand à l'époque du 4 e jour du 5 me mois de l'an de la V(raie) L(umière) 5812 (SAO); Tableau des $\mathrm{F}$ (rères) composant la R(espectable) L(oge) de St. Jean sous le titre distinctif du Septentrion à l'O(rient) de Gand à l'époque du 2 me jour du 11 me mois de l'an de la V(raie) L(umière) 5818 (SAO); Tableau des Membres composant la L(oge) de St. Jean sous le titre distinctif du Septentrion à l'O(rient) de Gand à l'époque du $8 \mathrm{me}$ jour du ler mois de l'an de la V(raie) L(umière) 5823 (SAO, Vrijmetselarij, 18 c, 45).

36 Ledenlijst van 8/1/5823 (8/3/1823) (Archief van het bisdom Brugge, Brugge).

37 De Commissie van Officieren-Dignitarissen, hierna COD genoemd. Hoofdstuk I van het reglement van 1818 behandelt de COD. Volgens artikel 2 wordt de loge bestuurd door deze officieren. Haar werking wordt niet apart genotuleerd.

38 Tableau des Off(iciers-dignitaires) et des F(rères) qui composent la R(espectable) L(oge) de Saint-Jean, sous le titre distinctif Le Septentrion, à l'O(rient) de G(and) (régulièrement constituée par le G(rand) O(rient) de France le 4ème jour du 8ème mois, de l'an de la V(raie) L(umière) 5812) à l'époque du lier jour du Gème mois de l'an de la V(raie) L(umière) 5814 (Liberaal Archief); Tableau des Membres effectifs et résidants, composant la L(oge) de St. Jean sous le titre distinctif du Septentrion à l'O(rient) de Gand, régulièrement constituée par le G(rand) $\mathrm{O}$ (rient) de France le $4^{\mathrm{e}}$ jour du $8^{\mathrm{e}}$ mois 5812 . Certifié véritable le présent tableau de Gand le $15^{\mathrm{e}}$ jour du $3^{\mathrm{e}}$ mois de l'an 5816 (Liberaal Archief).

39 Nederland, Den Haag, Maçonniek Centrum Prins Frederik, Tabel der Achtbare Loge Le Septentrion te Gent loopende van primo 1853 tot en met ultimo Maart 1854, Tabel der Achtbare Loge Le Septentrion te Gent loopende van primo 1854 tot en met ultimo Maart 1855, Tabel der Achtbare Loge Le Septentrion te Gent loopende van primo 1855 tot en met ultimo Maart 1856, Tabel der Achtbare Loge Le Septentrion te Gent loopende van primo 1856 tot en met ultimo Maart 1857, Tabel der Achtbare Loge Le Septentrion te Gent loopende van primo 1857 tot en met ultimo Maart 1858, Tabel der Achtbare Loge Le Septentrion te Gent loopende van primo 1858 tot en met ultimo Maart 1859.

40 2.A.10/(2.0693), Livre des listes des présences (1854-1862). 
Voor de volledigheid meld ik dat de primaire bronnen ontoegankelijk waren gedurende meer dan 50 jaar. De Duitsers stelden de vrijmetselarij op 20 augustus 1941 buiten de wet. ${ }^{41}$ Hun archieven werden overgebracht naar Berlijn. Na de Russische bezetting van Berlijn werden deze dossiers overgebracht naar Moskou. Hier ontdekten Belgische vorsers in 1992 in de geheime Russische militaire archieven onder andere de maçonnieke archieven. In mei 2002 werden alle Belgische archieven opgehaald met vijftien legervrachtwagens. Deze werden niet aan de diverse loges gerestitueerd maar overgedragen in 2003 aan het Cedom-Madoc in Brussel. $^{42}$

\section{Het onderzoek in zijn context geplaatst}

Mijn onderzoek heeft een repertorium opgeleverd dat profane en maçonnieke gegevens van 736 vrijmetselaars omvat. Die zijn allen ingewijd of geaffilieerd in de periode 1811 tot 1867 . Op basis van de bekende ledenlijsten alleen, zou het repertorium slechts 373 namen bevatten. De innovatie schuilt in het naspeuren van de primaire bronnen op initiaties en affiliaties, wat een lijst van 697 leden oplevert. Beide lijsten leiden tot een repertorium met de namen van 736 vrijmetselaars. Daaruit blijkt dat 39 vrijmetselaars wel op ledenlijsten vermeld staan maar voorts nergens in de bronnen. Een aantal verslagen ontbreken of zijn onleesbaar. ${ }^{43}$

Een aantal personen werden geïnitieerd maar lieten nadien niets meer van zich horen. Het ging vaak over vreemdelingen op doorreis of Gentenaars die voor een langere periode of definitief naar het buitenland vertrokken. Vaak werd hen op de-

41 "Verordening van 21 Augustus 1941 tegen de vrijmetselarij", Verordnungsblatt der Militärbefehlshabers in Belgien und Nordfrankreich für die bezetzten Gebiete, 23 august 1941. Deze verordening werd getekend door Alexander von Falkenhausen. De goederen van de werkplaatsen werden verbeurd verklaard en de chef van het militair bestuur benoemde een vereffenaar.

42 Jacques Lust en Michel Vermote, "Papieren Bitte! The confiscation and return of Belgian archives and libraries (1940-2003)," in Returned from Russia?: Nazi archival plunder in Western Europe and recent restitution issues, eds. Kennedy Grimsted Patricia, Hoogewoud FJ en Ketelaar Eric (Builth Wells, UK: Institute of Art and Law, 2007), 195-96, 202-03, 209-10. Mijn masterscriptie en dit artikel konden niet geschreven worden zonder consultatie van deze archieven.

43 2.A.10/(1.0632), Livre d'architecture (1837-1843), 1840-05-12-90: het LA (Livre d'architecture) springt van bladzijde 90 naar 91b; 1842-09-13-155: de verslagen 387 en 388 ontbreken. Het LA springt van bladzijde 152 naar 155; 1840-05-12-91b: bladzijde 91 ontbreekt en bevat onder andere de verkiezing van de COD; 1841-04-06-115: bladzijde 115b en verslag 355 ontbreken; 1842-06-21-152: verslag 387 en 388 ontbreken evenals bladzijden 153 en 154; 1843-11-11-195: Verslag 425 en 426 ontbreken evenals bladzijden 196 en 197; 2.A.10/(1.0633), Livre d'architecture (Premier grade) (1844-1853): ontbrekende bladzijden: $66,156,160,164,183,219,222,264 ; 2 . A .10 /(1.0638)$, Livre d'architecture (1 degré) (1854-1863): ontbrekende bladzijden: 226, 227, 297 tot 304; 128b tot 139, 182, 195 en 240, 43b tot 47 tot 50; bladzijde 92 bestaat 2 keer; de verslagen 907 tot 909 ontbreken evenals verslag 919; pagina 240 en 244 ontbreken maar de nummering van het verslag is correct; LA 1863-1868: de verslagen 968 (p 30-34), 978 en 979 (p53-57), 992 en 993 ontbreken; 2.A.10/(1.0640), Livre d'architecture (1 degré) (1863-1868): bladzijden 93 tot 97, 102 tot 108,129 tot 130 ontbreken. 
zelfde dag de drie graden van de blauwe rite toegekend. ${ }^{44}$ Zo werden de eerste decennia veel militairen geïnitieerd. De wisselende slaagkansen op het slagveld of de verplaatsing van regimenten zorgden voor komende en gaande vrijmetselaars. Het repertorium bevat ook de namen van 45 ereleden. Die titel werd onder andere wegens verdienste in de werkplaats toegekend aan oudere leden. Achtbare meesters van andere werkplaatsen genoten eveneens dit voorrecht. Sommigen hadden amper een band met Le Septentrion. Zo werden een aantal Nederlanders tot erelid benoemd die geijverd hadden voor de opname van Le Septentrion in de obediëntie Grootoosten van Nederland. De ereleden werden daarom uit de onderzoeksgroep geweerd.

\section{Enkele relevante personalia}

Dit elementair prosopografisch onderzoek start met een analyse van de geboorteplaats. Van 618 op 736 vrijmetselaars (84\%) is de plaats van geboorte bekend. Zoals te verwachten valt, en wat ook uit tabel 1 blijkt, werden 306 (46,76\%) vrijmetselaars in Gent ${ }^{45}$ geboren. Meer dan $61 \%$ is van Oost-Vlaamse origine: SintNiklaas is na Gent koploper als geboorteplaats van acht vrijmetselaars. Zes vrijmetselaars zijn geboren in Lokeren en Ronse; vijf in Oudenaarde, Ninove en Deinze; vier in Dendermonde en Aalst. In België maar buiten Oost-Vlaanderen, werden 133 vrijmetselaars ingewijd, wat een gecumuleerd resultaat voor België van 83\% geeft. De meeste vrijmetselaars zijn in de grote steden geboren zoals Antwerpen (13), Brugge (12) en Brussel (11). Buiten België is het voornamelijk in de buurlanden Frankrijk (34), Nederland (35) en Duitsland (19), dat de vrijmetselaars geboren werden. De Noordzee is duidelijk een belemmering want slechts acht vrijmetselaars zijn in het Verenigd Koninkrijk geboren. Omdat in de besproken periode Gent driemaal van regime veranderde en dit niet bepaald vredevol is, wordt de geboorteplaats van de vrijmetselaars-militairen nader bekeken. Die is van 52 onder hen bekend. Voor slechts tien vrijmetselaars-militairen is dit Gent, terwijl 21 onder hen in het buitenland geboren zijn. Waar dus globaal $17 \%$ van de vrijmetselaars in het buitenland geboren is en $46,76 \%$ in Gent, is slechts $19 \%$ van de militairen in Gent geboren en $40 \%$ in het buitenland.

44 Dit verwijst naar de graden van leerling, gezel en meester.

45 Met Gent wordt de stad bedoeld namelijk het grondgebied tot voor de fusie van de gemeenten in 1976. De deelgemeenten zoals Ledeberg, Drongen, ... zijn opgenomen onder Oost-Vlaanderen. 
Tabel 1: Geboorteplaats van de vrijmetselaars van le Septentrion

\begin{tabular}{|l|r|r|c|}
\hline \multicolumn{1}{|c|}{ Locatie } & Aantal & Percent & Percent cumul \\
\hline Gent & 289 & $46,76 \%$ & $46,76 \%$ \\
\hline Oost-Vlaanderen & 91 & $14,72 \%$ & $61,48 \%$ \\
\hline België & 133 & $21,52 \%$ & $83,00 \%$ \\
\hline Nederland & 35 & $5,66 \%$ & $88,66 \%$ \\
\hline Frankrijk & 34 & $5,50 \%$ & $94,16 \%$ \\
\hline Duitsland & 19 & $3,07 \%$ & $97,23 \%$ \\
\hline Verenigd Koninkrijk & 8 & $1,29 \%$ & $98,52 \%$ \\
\hline Oostenrijk Hongarije & 3 & $0,49 \%$ & $99,01 \%$ \\
\hline Turkije & 2 & $0,32 \%$ & $99,33 \%$ \\
\hline Luxemburg & 1 & $0,16 \%$ & $99,49 \%$ \\
\hline Griekenland & 1 & $0,16 \%$ & $99,65 \%$ \\
\hline Zwitserland & 1 & $0,16 \%$ & $99,81 \%$ \\
\hline Brazilië & 618 & $0,16 \%$ & $99,97 \%$ \\
\hline Totaal & & $100,00 \%$ & \\
\hline
\end{tabular}

Het is niet omdat een vrijmetselaar in Gent geboren is dat hij er ook verblijft. Van 562 vrijmetselaars is de verblijfplaats bekend; 442 vrijmetselaars $(78,65 \%)$ geven Gent als plaats van domiciliëring op. Bij de loge La Liberté ligt dit cijfer lager. Van de eerste 150 leden geven er 89 te kennen dat zij in Gent woonachtig zijn. ${ }^{46}$ Voor de niet-residerende leden werd in de $19 \mathrm{de}$ eeuw soms een broederkring (cercle fraternel of loge d'agrégés) opgericht. Zij konden zich niet altijd naar een werkplaats verplaatsen en de broederkring liet hen toe samen te komen. René Vermeir toont aan dat La Liberté met de oprichting van broederkringen vrij snel een aanvang nam. ${ }^{47}$ De enige mogelijke verklaring van het verschillende percentage qua woonplaats luidt dat vrijmetselaars buiten Gent sneller zouden toetreden tot La Liberté, omdat deze werkplaats actiever broederkringen oprichtte. Van die gewoonte heb ik geen sporen aangetroffen in de archieven van Le Septentrion voor de besproken periode. Jeffrey Tyssens deed onderzoek naar de woonplaats van de leden van de Gentse werkplaatsen. Hij baseerde zich op de analyse van vijf ledenlijsten (La Félicité Bienfaisante 1813, Le Septentrion 1854 en 1883, La Liberté 1874 en 1901). Hij stelde vast dat het aantal in Gent wonende leden zeer groot was, maar dat in de

46 Vermeir en Tyssens, Vrijmetselarij en Vooruitgang, 110-12.

47 Vermeir en Tyssens, Vrijmetselarij en Vooruitgang, 107. 
tweede helft van de 19de eeuw minstens een deel op meer dan 20 kilometer van de werkplaats gedomicilieerd was. ${ }^{48}$ Samenvattend concludeer ik dat Le Septentrion toch in de eerste plaats een Gentse werkplaats was, ook al had zij niet-residerende leden en werden passanten ingewijd, met wie nadien elk contact verloren ging. Het relatief groot aantal vrijmetselaars van buitenlandse origine hield verband met hun militaire aanwezigheid in Gent.

Omdat deze studie zich uitstrekt over een welbepaalde periode, is de geboorteof sterftedatum van de vrijmetselaars op zich niet relevant. Het geeft wel een idee van de leeftijd die de vrijmetselaars bereikten. De gegevens zijn wel beperkt in die zin dat slechts van 137 vrijmetselaars $(18,46 \%)$ het jaar van geboorte en van overlijden bekend is. ${ }^{49}$ De jongste vrijmetselaar overleed op 21 jaar, de oudste vrijmetselaar werd 96 jaar. Gemiddeld werden de vrijmetselaars 61,91 jaar.

De leeftijd waarop de profaan toetreedt tot Le Septentrion is een onderzoek waard. Van 541 vrijmetselaars $(73,5 \%)$ is de leeftijd van inwijding bekend. De gemiddelde leeftijd bedroeg 31,09 jaar. De jongste elf profanen werden op 19 jaar ingewijd en de oudste profaan was 74 jaar. ${ }^{50}$ De gemiddelde leeftijd ligt in de lijn van de berekeningen die René Vermeir maakte voor La Liberté. Hij stelde vast dat de gemiddelde leeftijd waarop vrijmetselaars ingewijd werden voor de periode 1866 1914 net geen 32 jaar bedroeg. ${ }^{51}$ In de Antwerpse loge Marnix van Sint-Aldegonde bedroeg de gemiddelde leeftijd slechts 26 jaar in de periode 1900-1909. In het volgende decennium stijgt deze wel naar 33 jaar, wat overeenkomt met de Gentse resultaten. ${ }^{52}$ In de West-Vlaamse loge L'Amitié schommelde de gemiddelde leeftijd tussen 33 en 37 jaar in de periode 1803-1833. De oudste profaan was 59 jaar, de jongste 17 jaar. ${ }^{53}$ Een verklaring voor dit verschil heb ik niet gevonden. Jacques Mertens heeft wel vastgesteld dat de gemiddelde leeftijd lager ligt dan vandaag, 'wat gezien onze langere levensverwachtingen niet moet verbazen'. ${ }^{4}$

\footnotetext{
48 Jeffrey Tyssens, In vrijheid verbonden. Studies over Belgische vrijmetselaars en hun maatschappijproject in de

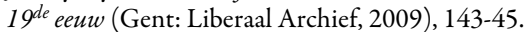

49 Van 438 vrijmetselaars is het geboortejaar bekend. Het jaar van overlijden is eerder problematisch.

50 Normaal moest men 21 jaar zijn, maar kinderen van vrijmetselaars konden vanaf 18 jaar intreden.

51 Vermeir en Tyssens, Vrijmetselarij en Vooruitgang, 105.

52125 jaar | 5890 - 6015 |Achtbare loge Marnix van Sint-Aldegonde Oosten Antwerpen (Antwerpen: Marnix van Sint-Aldegonde, 2015), 96-7.

53 Jacques Mertens, "De vrijmetselarij in West-Vlaanderen: een sociologische benadering," in De heeren broederkes van den moortelbak: 250 Jaar Vrijmetselarij In West-Vlaanderen, eds. Tyssens Jeffrey en Dendooven Dominiek (Brussel: ASP, 2015), 185-86.

54 Tyssens en Dendooven, De heeren broederkes van den moortelbak, 187.
} 
De aanstelling van Reytter tot achtbare meester op 21 december 1821 leidde tot een periode van crisis." " Staking van de activiteiten of een fusie met de loge Les Vrais Amis wordt overwogen. Zover komt het niet. Er wordt een nieuw gebouw gevonden en Steven wordt op 12 december 1829 aangesteld tot achtbare meester. Hij is aangesloten bij de werkplaats Les Vrais Amis en was reeds erelid van Le Septentrion. Hij zal de teloorgang een halt toeroepen. Pas na de aanstelling van Hippolyte Metdepenningen op 4 juni 1831 komt de maçonnieke en politieke revival van Le Septentrion op gang. ${ }^{56}$ Daarom is het interessant na te gaan of er een spectaculaire stijging van het aantal inwijdingen op gang kwam. Van 619 vrijmetselaars is het jaar van initiatie gekend. Een eerste piek in het aantal inwijdingen situeert zich na de oprichting. Van 1822 tot 1829 daalt het aantal inwijdingen van 10 per jaar tot bijna geen meer. Met de komst van achtbare meester Steven breekt een nieuwe positieve trend aan. Hippolyte Metdepenningen versterkt die trend de eerste vijf jaar van zijn veneralaat.

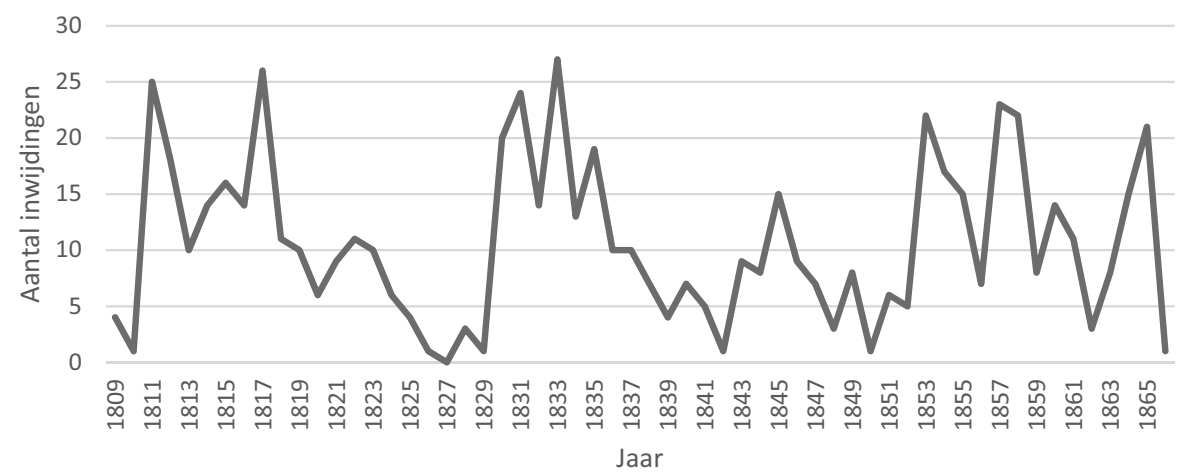

Grafiek 1: Aantal inwijdingen per jaar in Le Septentrion tussen 1811 en 1866

55 Désiré Destanberg, Histoire de la Respectable Loge de St.-Jean sous le titre distinctif du Septentrion à l'Orient de Gand. 5811-5911, (Gent: Hoste, 1911), 51. "Sous son vénéralat il ne se passa rien de particulier; beaucoup de membres démissionnèrent; les autres n'assistaient que très irrégulièrement aux tenues. Cette diminution de vitalité et d'activité fut le résultat de la vie calme, de la prospérité dont jouissait la ville de Gand après les multiples te longues luttes, qui l'avaient sécouée depuis 5789 (1789). Le Vénérable Maître Reytter lui-même de laissa entrainer par l'insouciance ou par l'indifférence; son manque de zèle lui fut rappelée par une planche dont la rédaction avait été arrêtée en tenue du 19 jour 5 mois 5822. Le frère sécretaire était aussi toujours absent. Le septentrion traversa une pénible crise. Le 27 jour 8 mois 5827 le frère orateur déclara en loge qu'ayant consulté le tableau des membres de l'Atelier il avait vu que les recettes ne pouvaient plus couvrir les dépenses et qu'il proposait la cessation momentanée des travaux ou la réunion de notre Atelier aux Vrais Amis."

56 Destanberg, Histoire de la Respectable Loge de St.-Jean, 53-4. Hippolyte Metdepenningen, geboren op 21 maart 1799, sloot zich aan bij Les Vrais Amis in de loop van 1829. Hij affilieerde op 12 augustus 1830 bij La Félicité Bienfaisante. Op advies van eerste opziener Colson van Le Septentrion affilieerde hij bij Le Septentrion op 25 januari 1831 . Op 8 maart 1831 werd hij tot achtbare meester verkozen. Hij werd geïnstalleerd als achtbare meester op 4 juni 1831. 


\section{De aanwezigheid in de werkplaats}

Om een idee te krijgen van de aanwezigheid kan worden gebruik gemaakt van een verslagboek waarin voor de periode 1853 tot 1861 de aanwezige vrijmetselaars per zitting geacteerd staan. ${ }^{57}$ Voor de jaren 1853 tot 1858 zijn ledenlijsten bewaard met een samenvattend overzicht. ${ }^{58}$ De combinatie van beide lijsten geeft ons een beeld van de ledenevolutie en van de aanwezigheid binnen de werkplaats. Vooraleer de bespreking ervan aan te vatten moeten die jaren in hun historische en maçonnieke context geplaatst worden. Zoals reeds vermeld werd, kenmerken die jaren zich door tegenvallende kiesresultaten voor de liberalen in Gent, ultramontaanse aanvallen op de vrijmetselarij en het verdwijnen van drie van de vier loges in Gent. ${ }^{59}$ Dit laatste feit verklaart de stijging van het aantal vrijmetselaars van 69 in 1853 tot 107 in 1858 . Voornamelijk actieve vrijmetselaars zijn voor de instroom verantwoordelijk. Waar gemiddeld 19,76\% van de vrijmetselaars niet in Gent resideerde en dus ook geen bijdrage betaalde en niet deelnam aan de zittingen, daalde hun aandeel van $33 \%$ in 1853 naar 14\% in 1858. De instroom is het sterkst in de jaren 1853 en 1854 als telkens ongeveer 40\% nieuwe leden zich presenteren. Gemiddeld $12 \%$ van het totaal aantal leden overlijdt of verlaat de werkplaats. Enkel in 1855 ligt dit percentage op 23\%. Hierbij valt op dat velen die Le Septentrion verlieten in 1853 en 1854 pas het jaar daarvoor geïnitieerd of geaffilieerd waren. Een formele verklaring heb ik in de bronnen niet gevonden, maar het ligt voor de hand dat zij zich misschien minder goed thuis voelden in hun nieuwe werkplaats of dat de nieuwe werkplaats die stroom aan nieuwe vrijmetselaars onvoldoende kon assimileren. De winterzonnewendefeesten ${ }^{60}$ niet meegerekend, bedroeg de gemiddelde aanwezigheid slechts $24,48 \%$. Hierbij moet rekening gehouden worden

57 2.A.10/(2.0693), Livre des listes des présences (1854-1862).

58 Nederland, Den Haag, Maçonniek Centrum Prins Frederik, Tabel der Achtbare Loge Le Septentrion te Gent loopende van primo 1853 tot en met ultimo Maart 1854, Tabel der Achtbare Loge Le Septentrion te Gent loopende van primo 1854 tot en met ultimo Maart 1855, Tabel der Achtbare Loge Le Septentrion te Gent loopende van primo 1855 tot en met ultimo Maart 1856, Tabel der Achtbare Loge Le Septentrion te Gent loopende van primo 1856 tot en met ultimo Maart 1857, Tabel der Achtbare Loge Le Septentrion te Gent loopende van primo 1857 tot en met ultimo Maart 1858, Tabel der Achtbare Loge Le Septentrion te Gent loopende van primo 1858 tot en met ultimo Maart 1859.

59 De werkplaatsen Les Vrais Amis (1853), La Félicité Bienfaisante (1855) en La Fidélité (1854) verdwenen in die periode. Le Septentrion was toen de enige loge in Oost- en West-Vlaanderen. Pas met de oprichting van de loge La Liberté ontstond in Gent terug een tweede werkplaats.

60 Eind december begin januari organiseerde Le Septentrion jaarlijks een feest. Op dit feest werd de nieuwe Commissie van Officieren-Dignitarissen geïnstalleerd. Delegaties van andere werkplaatsen werden ontvangen. De redenaar hield een gelegenheidstoespraak, waarbij hij onder andere het verlopen jaar besprak. Jubilarissen (vrijmetselaars met 25 jaar maçonnieke arbeid op de teller) werden geëerd. De feestelijke zitting ging verder aan tafel. Tijdens het souper (het broedermaal in maçonnieke termen) werden de verplichte heildronken uitgebracht. Het feest werd opgeluisterd door een orkest (in maçonnieke termen harmoniekolom genoemd). 
dat de circa 20\% niet-contribuerende vrijmetselaars de zittingen niet moesten bijwonen. Tussen 1853 en 1861 waren op dit jaarlijks feest minstens 64 vrijmetselaars op 24 december $1859^{61}$ en zelfs 105 vrijmetselaars op 8 januari $1858^{62}$ aanwezig.

In de schaarse literatuur over Le Septentrion wordt vaak aangehaald dat de achtbare meester Hippolyte Metdepenningen na verloop van tijd zo goed als nooit naar een zitting kwam en zich liet vervangen door dokter Edouard Brébart. Ik heb de aanwezigheid van Hippolyte Metdepenningen nagekeken voor de periode 18531861 en ik kan dit gerucht enkel bevestigen. In die periode werd hij als voorzittend meester voor de 22ste tot de 30ste keer herkozen. Er werden 274 zittingen gehouden, waarop Metdepenningen 44 keer aanwezig was (16,06\%). Dit percentage is nog geflatteerd want binnen die periode nam hij tussen 17 november 1858 en 26 februari 1858 aan vijftien van de achttien zittingen deel. ${ }^{63}$ Tot eind 1860 werd bij afwezigheid van Metdepenningen de zitting geleid door Brébart. Nadien leidde Jules Guéquier de zittingen tot het einde van het register.

\section{Molière maar ook Vondel}

Bijna alle primaire bronnen zijn geschreven in het Frans. Occasioneel werd in het Nederlands gecorrespondeerd met het Grootoosten van Nederland. Frans was de voertaal bij de vrijmetselaars van Le Septentrion, net zoals in de betere milieus van de profane wereld. Tussen 1830 en 1850 verfransten de loges en de bourgeoisie nog in Vlaanderen. Pas na 1860 krijgen pro-Vlaamse progressisten invloed in de loges. ${ }^{64}$ In de primaire bronnen van de bestudeerde periode heb ik geen negatieve uitlatingen gevonden over Vlamingen of het Nederlands. Er zijn een aantal documenten bewaard voor de periode 1833 tot 1866, waarin gepeild wordt naar de overtuiging van profanen die om inwijding in de werkplaats verzoeken. ${ }^{65} \mathrm{Zij}$ moeten vooraf schriftelijk een aantal vragen beantwoorden. Van 220 vrijmetselaars

61 2.A.10/(2.0693), Livre des listes des présences (1854-1862), 20170829_114126.jpg en 20170829_ 114118.jpg.

62 2.A.10/(2.0693), Livre des listes des présences (1854-1862), 20170829_113817.jpg en 20170829_ 113823.jpg.

63 2.A.10/(2.0693), Livre des listes des présences (1854-1862), 20170829_113915, 20170829_113921, 20170829_113932, 20170829_113938, 20170829_114000, 20170829_114008, 20170829_114017, 20170829_114025.

64 Els Witte, "La Franc-maçonnerie belge face au mouvement flamand du XIX siècle," in Visages de la FrancMaçonnerie belge du xviiie au xxe siècle, eds. Hasquin Hervé (Brussel: Editions ULB, 1983), 248-52.

65 2.A.10/(1.0656), Correspondances diverses. Documents (dont certains en néerlandais) sur des initiations et augmentations de salaire (1833-1853);2.A.10/(1.0639), Registre des planches des travaux de compagnons (1856-1892). (Documents insérés sur des demandes d'initiations et d'augmentations de salaire); 2.A.10/ (1.0678), Documents sur initiations et augmentations de salaire (1860-1866). Docc. 15-221 demandes d'initiations (1860). 
$(27,8 \%)$ heb ik documenten gevonden die verwijzen naar hun taalgebruik. Onder hen beantwoorden 187 vrijmetselaars (85\%) de vragen in het Frans en 33 (15\%) in het Nederlands. In de besproken periode was Le Septentrion dus zeker geen antiVlaams gezelschap. De taalproblematiek stelde zich gewoon niet en er was respect voor de profanen, die het Frans minder goed machtig waren. ${ }^{66}$ Op het einde van de bestudeerde periode blijkt wel dat de vrijmetselaars van Le Septentrion nu ook weer niet de vaandeldragers waren van de Vlaamse zaak of van de vernederlandsing van het openbare leven. Een aantal vrijmetselaars waren individueel de Vlaamse zaak wel genegen. De oprichting van La Liberté had voor gevolg dat de protagonisten van de Vlaamse zaak over twee werkplaatsen verspreid raakten. Jules de Vigne trok naar La Liberté; Julius Vuylsteke en Paul Fredericq bleven in Le Septentrion. Elk loge-initiatief omtrent een grotere rol van het Nederlands in het maatschappelijke leven werd onhaalbaar. ${ }^{67}$

\section{De geloofsovertuiging bij de intrede}

In dezelfde documenten met gegevens over profanen die om opname in Le Septentrion verzoeken, wordt ook de vraag gesteld naar de geloofsovertuiging van de profaan in kwestie.

Voor 170 vrijmetselaars (op 736 dus 23,1\%) kennen we het antwoord. Hun geloofsovertuiging is opgenomen in tabel 2. Meer dan $70 \%$ geeft aan katholiek te zijn. Zoals eerder vermeld, dateert de episcopale oekaze, die gelovigen verbood tot de vrijmetselarij toe te treden, van $1838 .{ }^{68}$ Theoretisch zou het mogelijk zijn dat de intrede van katholieke vrijmetselaars zich situeert tussen 1811 en 1837 . De beschikbare gegevens starten pas in 1833 . Van zeven vrijmetselaars is het jaar van initiatie niet bekend. Slechts vijf katholieken zijn ingewijd vóór 1837. De andere 110 vrijmetselaars zijn ingewijd vanaf 1838 tot 1866 . Guy Schrans schrijft hierover het volgende: "In 1839 maakte Le Septentrion een einde aan de praktijk om aan kandidaten de schriftelijke vraag te stellen "dites nous à quelle réligion vous appartenez." Désiré Destanberg preciseert dat tot dan "la réligion catholique romaine" het tradi-

66 2.A.10/(1.0627), Livre d'architecture (1816-1828).1823-03-12-107. Bij de initiatie van Laridon wisselt de Achtbare Meester: "le frère Rousseau a bien voulu se charger du ler maillet, la langue flamande étant plus familiaire au profane.”; 2.A.10/(1.0627), Livre d'architecture (1816-1828). 1823-03-25-107b. Bij de inwijding van Jonglar draagt vrijmetselaar Notte de eerste hamer, omdat de profaan de Hollandse taal beter begrijpt. 2.A.10/(1.0627), Livre d'architecture (1816-1828). 1825-01-20-116. Bij de initiatie van Van Hoeyvelde David hanteert Notte om dezelfde reden terug de eerste moker.

67 Bart D'Hondt, Van Andriesschool tot Zondernaamstraat, Gids door 150 jaar liberaal leven te Gent (Gent: Uitgeverij Snoeck, Liberaal Archief, 2014), 23.

68 Aloïs Simon, L'hypothèse libérale en Belgique: documents inédits 1839-1907 (Wetteren: Scaldis, 1956), 154; Bartier en Gambier, Laïcité et franc-maçonnerie, 227; Arvelle, Histoire de la franc-maçonnerie belge, 69. 
tionele antwoord was. ${ }^{69}$ Zoals hiervoor vermeld spreekt mijn analyse dit tegen. Désiré Destanberg heeft blijkbaar nooit de vragenlijsten die profanen invullen geconsulteerd en Guy Schrans heeft die bedenking overgenomen. De opname van vijftien protestantse profanen vindt zijn oorsprong in de goede banden met Nederland en het arbeiden onder het Grootoosten van Nederland. Slechts één protestantse vrijmetselaar geeft op in Antwerpen geboren te zijn; de meerderheid (9) is in Nederland geboren. De resterende vijf zijn in Frankrijk, Londen (1) of het Groot Hertogdom Luxemburg (1) geboren. De twee Joden zijn Alphonse Huisman, student rechten, en Arthur Alexandre, handelaar, beiden in Gent geboren. Emmanuel-Pantaléon Schilizzi (Chio, Turkije) en Jean-Démétrius Cambanis (Andros, Griekenland) geven op Grieks-orthodox te zijn. De rubriek 'andere' is een amalgaam. Sommige kandidaten zijn onduidelijk in hun antwoord: "Je crois en Dieu" (Charles-Armand De Ketelaere en Léon Vanden Bossche), "La même réligion de mon père” (Pierre-Auguste Doublet), “... catholique, mais je crois en rien” (Jean Rommel fils), "La réligion de l'honnête homme" (Prosper Claeys) en "La réligion naturelle" (Edmond Wolfcarius). Het is duidelijk dat katholieken niet enkel de grootste groep vormen, maar ook na het episcopale verbod om opname bleven verzoeken. Om het lidmaatschap van de werkplaats na te streven hoeven kandidaten dus allerminst ongelovig te zijn.

Tabel 2: Indeling per confessionele overtuiging van profanen die om opname in de loge verzoeken

\begin{tabular}{|l|c|c|}
\hline \multicolumn{1}{|c|}{ Geloofsovertuiging } & Aantal & Percentage \\
\hline Katholiek-christelijk & 122 & $71,8 \%$ \\
\hline Protestant & 15 & $8,8 \%$ \\
\hline Ongelovigen & 13 & $7,7 \%$ \\
\hline Grieks-orthodox & 2 & $1,2 \%$ \\
\hline Joods & 2 & $1,2 \%$ \\
\hline Gereformeerd & 1 & $0,6 \%$ \\
\hline Ander & 15 & $8,8 \%$ \\
\hline Totaal & 170 & $100,0 \%$ \\
\hline
\end{tabular}

69 Schrans, Guy, "Politiek en religie in de negentiende-eeuwse Gentse vrijmetselaarsloges." in 35 Jaar Erfgoedbeleid?: 35 Jaar Liberaal Archief, eds. Jan Kerremans, Peter Laroy en Walter Prevenier (Gent: Liberaal Archief 2016), 106, voetnoot 5; Désiré Destanberg, Histoire de la Respectable Loge de St.-Jean sous le titre distinctif du Septentrion à l'Orient de Gand. 5811-5911 (Gent: Hoste, 1911), 86-7. 
Kunnen die resultaten nu een verrassing genoemd worden? Om die vraag te beantwoorden plaats ik ze in een bredere context. Waar komt de aanwezigheid van religie in werkplaatsen vandaan? Maurice Agulhon stelt dat “... l'abandon des confréries de pénitents pour les loges maçonniques n’a pas été le fait individuel de quelques rares esprits marqués, mais au contraire un fait assez général, un fait quasi collectif, un phénomène déjà social." ${ }^{\text {70 }} \mathrm{Hij}$ ziet een aantal analogieën tussen 'Les confréries des pénitents' en de loges: het gebruik van het woord 'vrijmetselaar', het cultiveren van ceremonie, vriendschap, hulp en bijstand, het belang van de beoefening van liefdadigheid, het geheime karakter, de speciale interesse voor begrafenissen. Deze gemeenschappelijke kenmerken zijn nog sterker aanwezig bij gelaïciseerde broederschappen. ${ }^{71}$ Christophe Verbruggen kadert die overgang in de vraag naar de mate van continuïteit tussen de vroegmoderne en de moderne tijd. Burgerverenigingen bestonden al onder de vorm van broederschappen, gilden en schuttersverenigingen. De Wet Le Chapelier verbood in 1791 de corporatistische organisaties. ${ }^{72}$ Agulhon benadrukt het progressieve karakter van de werkplaatsen onder invloed van de moderne ideeën van de verlichting. Loges hebben de liberale beweging geholpen. Ze nemen ook progressieve standpunten in om de sociale barrières te slechten. Op ideologisch vlak blijven loges respectvol tegenover vorst en kerk. ${ }^{73}$ Naast de reeds aangehaalde argumenten kan dit laatste mede verklaren waarom zoveel vrijmetselaars opgeven religieus te zijn. Religiositeit in Vlaanderen komt grotendeels overeen met het belijden van het katholieke geloof.

\section{Het beroepsprofiel}

In de volgende paragraaf onderzoek ik het beroep dat de leden van Le Septentrion uitoefenden. De onderzoeksresultaten moeten in een bredere context bekeken worden. Daarom zal ik de resultaten toetsen aan de beroepen die de leden van La Liberté, van de West-Vlaamse loge L'Amitié en van de Antwerpse loge Marnix van Sint-Aldegonde uitoefenden.

\footnotetext{
70 Maurice Agulhon, Pénitents et Francs-Maçons de l'ancienne Provence (Paris:Librairie Fayard,1968), 198.

71 Agulhon, Pénitents et Francs-Maçons de l'ancienne Provence, 206-09.

72 Christophe Verbruggen, "Het verenigingsleven en de publieke ruimte 1815-1830," in Het (on)verenigd Koninkrijk Der Nederlanden, 1815-1830 > 2015. Een Politiek Experiment In De Lage Landen, eds. Deneckere Gita en Aerts Remieg (Rekkem: Ons Erfdeel vzw, 2015), 111.

73 Agulhon, Pénitents et Francs-Maçons de l'ancienne Provence, 186.
} 
Van ongeveer $85 \%$ van de vrijmetselaars (626 op 736 vrijmetselaars) is het beroep bekend. Ik heb deze vrijmetselaars ingedeeld in negen hoofdcategorieën namelijk ambtenaren, journalisten-schrijvers, kunstenaars, leidinggevenden ${ }^{74}$, militairen, ondernemers, onderwijzers, renteniers, vrijmetselaars met een vrij beroep en werknemers. Onder de ambtenaren zijn alle vrijmetselaars opgenomen, die voor alle overheden in de ruimste zin van het woord werken. Onder de kunstenaars heb ik elke vrijmetselaar met artistieke kwaliteiten ingedeeld. Een aantal vrijmetselaars onder hen waren actief in de harmoniekolom, anderen zijn te vatten onder de noemer 'artiste peintre'. Onder de journalisten-schrijvers vallen zowel de zuivere journalisten als de 'homme de lettres'. In de categorie militairen zijn niet enkel de officieren in krijgsdienst opgenomen. Een aantal vrijmetselaars-militairen zijn arts, dierenarts of verantwoordelijke voor logies. Gewone soldaten werden niet geïnitieerd in de besproken periode. Ondernemers vormen de grootste groep. Het is een amalgaam van industriëlen, kooplui, handelaars, vertegenwoordigers, kleine zelfstandigen zoals horlogemakers, juweliers, ... kortom ieder die destijds onder het toepassingsgebied van het Wetboek van Koophandel van 1808 viel. Onderwijs omvat ook een diverse groep. Die groep omvat zowel de directeur van een school, een leraar van het atheneum als een hoogleraar aan de universiteit. De vrijmetselaars met een vrij beroep zijn voornamelijk artsen en advocaten en in mindere mate notarissen, gerechtsdeurwaarders en architecten. De werknemers en de leidinggevende vormen elk een kleine groep. Zij werken niet voor de overheid. Meest frequent komen hier de directeurs van commerciële bedrijven de kapiteins-ter-zee voor. De indeling in de diverse hoofdcategorieën was niet altijd evident. Soms werd een vrijmetselaar niet aan een beroepscategorie toegewezen zoals iemand die als beroep enkel 'ingenieur' vermeldt maar geen bedrijf of sector opgeeft. ${ }^{75}$ Een vrijmetselaar geeft soms meer dan één beroep op, waarbij het onmogelijk is om het hoofdberoep vast te leggen. Als een vrijmetselaar meerdere beroepen opgeeft en over een van de vermelde beroepen twijfel bestaat, is prioriteit gegeven aan het beroep waarover geen twijfel bestaat. Een profaan die bij zijn inwijding nog studeert maar zijn diploma behaalt, wordt ingeschaald op basis van zijn diploma. Het hoogste beroep wordt soms als doorslaggevend beschouwd. Wie als beroep advocaat en magistraat opgeeft, verschijnt in de lijst van de ambtenaren als magistraat. Als een vrijmetselaar zich manifesteert als advocaat, is onder de rubriek studies 'Rechtsgeleerdheid'

74 Onder de leidinggevenden groepeer ik de vrijmetselaars in loondienst met een verantwoordelijke functie. Deze vrijmetselaars maken deel uit van de directie van een bedrijf of zijn minstens volmachthouder. Onder die groep heb ik ook 'de kapiteins ter langen omvaart' ingeschaald. Ik heb mij hierbij gebaseerd op de bevoegdheden van een kapitein op een schip.guéquier.

75 Ingenieur is een titel die men verwerft bij het behalen van een diploma in de ingenieurswetenschappen. Dit is geen beroep. 
opgenomen. Dit gebeurt niet automatisch bij gerechtsdeurwaarders ${ }^{76}$ en notarissen. ${ }^{77} \mathrm{Zij}$ moesten in de besproken periode niet in het bezit te zijn van het diploma van doctor in de rechten. Tenslotte, als een profaan opgeeft dat zijn beroep in het buitenland verschilt van het beroep dat hij in België uitoefent, krijgt het in België uitgeoefende beroep prioriteit.

Tabel 3: Overzicht van de beroepscategorieën van de vrijmetselaars van Le Septentrion in de periode $1811-1866$

\begin{tabular}{|l|c|c|}
\hline \multicolumn{1}{|c|}{ Beroepscategorie } & Vrijmetselaars & Percentage \\
\hline Ambtenaar & 47 & $7,51 \%$ \\
\hline Journalisten-schrijvers & 9 & $1,44 \%$ \\
\hline Kunstenaar & 28 & $4,47 \%$ \\
\hline Leidinggevenden & 13 & $2,08 \%$ \\
\hline Militair & 70 & $11,18 \%$ \\
\hline Ondernemer & 326 & $52,08 \%$ \\
\hline Onderwijs & 25 & $3,99 \%$ \\
\hline Rentenier & 28 & $4,47 \%$ \\
\hline Vrij beroep & 70 & $11,18 \%$ \\
\hline Werknemer & 10 & $1,60 \%$ \\
\hline Totaal & 626 & $100,00 \%$ \\
\hline
\end{tabular}

\section{De ondernemers}

Elke beroepsgroep wordt nu besproken. Ik start met de meest omvangrijke groep namelijk de ondernemers. Uit tabel 3 blijkt dat iets meer dan de helft van de vrijmetselaars als ondernemer ingeschaald werd. Het is echter niet mogelijk in deze groep een lijn te trekken. Velen vallen onder de term 'négociant' of 'handelaar'. Dit kan zowel een detailhandelaar zijn als een handelaar die schepen vol koopwaar de

76 Bart Quintelier en Georges Martyn, "De juridische vrije beroepen," in Bronnen voor de studie van het hedendaagse België, 19e-21e Eeuw. 2e herziene en uitgebreide uitgave, eds. Van den Eeckhout Patricia en Vanthemsche Guy (Brussel: Koninklijke commissie voor geschiedenis, 2009), 1030. Pas sinds 2001 moet een kandidaat voor het ambt een universitair rechtendiploma behaald hebben en een stage van twee jaren volgen.

77 Fred Stevens, "Het notariaat," in Bronnen voor de studie van het hedendaagse België, eds. Van den Eeckhout Patricia en Vanthemsche Guy (Brussel: Koninklijke commissie voor geschiedenis, 2009), 663-68. Artikel 54 van de gecoördineerde wetten op het toekennen van academische graden en het programma van de universitaire examens van 31 december 1949 bepaalt dat, om tot notaris benoemd te worden, naast andere vereisten, de betrokkene het diploma van licentiaat in het notariaat moet bezitten. De vereiste dat de aflevering van het diploma licentiaat in het notariaat slechts toegestaan is na het behalen van het diploma van licentiaat in de rechten, werd ingevoerd door het koninklijk besluit tot wijziging van de gecoördineerde wetten op de toekenning van de academische graden en het programma van de universitaire examens met het oog op de oprichting van de graad van licentiaat in de rechten en de wijziging van het examenprogramma van licentiaat in het notariaat en van doctor in de rechten van 1 augustus 1969. 
wereld rondstuurt. Op basis van de onderzochte data kan een onderscheid niet gemakt worden. Omdat Gent beschouwd werd als het 'Manchester van het continent' zou een grote aanwezigheid van bestuurders, fabrikanten en handelaars in textiel en afgeleide producten voor de hand liggen. Slechts twintig vrijmetselaars kunnen bij deze groep ingedeeld worden.

Een andere indicatie om de groep ondernemers in te schatten vloeit voort uit een onderzoek naar de leden van de Kamer van Koophandel te Gent. ${ }^{78}$ Uit de ledenlijsten blijkt dat slechts veertien vrijmetselaars van Le Septentrion in de periode 1830-1866 lid zijn van de Kamer van Koophandel te Gent. Onder hen zijn er twee bankiers (Jules De Meulemeester en Charles De Buck), twee suikerraffinadeurs (Fidèle Mechelynck en Edouard Constant Neyt), twee industriëlen uit de scheikundige industrie (Edouard Jacquemeyns en Jules Leirens), een katoenfabrikant (Guillaume Van Zantvoorde), een handelaar in koloniale waren (Charles Van Duyn) en twee reders-bevrachter (Edouard Josse Coppens en Norbert-Joseph Claus). ${ }^{79}$ De analyse van het beroep van vrijmetselaars die lid zijn van de Kamer van Koophandel, leert dat de grotere industriëlen daartoe behoorden. Dat deze groep slechts uit veertien personen bestaat, bevestigt de stelling dat de superrijken in beperkte mate lid waren van Le Septentrion.

Ter vervollediging heb ik ook nog de banden onderzocht met de Cercle Commercial et Industriel. Dit was de officiële belangenvereniging van de machtigste en rijkste handelaars en industriëlen van Groot-Gent, opgericht in 1857. Haar meest spraakmakende initiatief was haar sociale inzet bij de katoencrisis van 1862, ontstaan ten gevolge van de Amerikaanse burgeroorlog. ${ }^{80}$ Ledenlijsten heb ik niet aangetroffen, maar uit het verslag van de bijstandscommissie van 20 november 1862 blijkt dat er 407.094,48 frank opgehaald werd en staan 73 namen vermeld van de burgers die de commissie voor de verdeling van de bijstand vormen. ${ }^{81}$ Slechts twaalf namen vind ik in het repertorium van Le Septentrion terug. De conclusie

78 Anna Van Der Kelen, "De kamer van koophandel te Gent (1830-1900)" (licentiaatsverhandeling, Universiteit Gent, 1987), 9-11, 15-7. De Kamers van Koophandel werden opgericht in de Franse periode door het besluit van de consuls van 3 novôse an XI ( 24 december 1802) in 22 grote centra. Het besluit van 7 floréal an XI (27 april 1803) voorzag onder andere in de oprichting van een Kamer van Koophandel te Gent. Zij hadden drie doelstellingen: plannen aan de overheid voorstellen om de handel te bevorderen, communiceren over de oorzaken die handel belemmerden en over de remedies. Tenslotte hielden zij ook toezicht op de uitvoering van openbare werken. Koning Willem I liet de Kamers van Koophandel verder bestaan en bevestigde dit in het organiek besluit van 8 oktober 1815. De Belgische onafhankelijkheid liet hen in grote lijnen verder bestaan. De Kamers van Koophandel werden op geen enkel moment in vraag gesteld. Zij werden wel verplicht jaarlijks een verslag te schrijven over de toestand in alle handels- en nijverheidssectoren van haar ambtsgebied. Zij hadden duidelijk een adviserende functie voor de overheid. Tevens verdedigden zij de belangen van de economie.

79 Van Der Kelen, “De kamer van koophandel te Gent (1830-1900)," 214-62.

80 D'Hondt, Van Andriesschool tot Zondernaamstraat, 278.

81 Cercle Commercial et Industriel de Gand. Rapport (Gand: Vanderhaeghen, 1862), 4. 
die geldt voor de Kamer van Koophandel is ook op de Cercle Commercial et Industriel van toepassing.

\section{De militairen}

De tweede groep omvat de 70 militairen. Naar militaire rang betreft het voornamelijk officieren met de rang van luitenant en in mindere mate die van kapitein. Onderofficieren zoals sergeanten, hoofdofficieren zoals majoors en kolonels, en opperofficieren zoals generaals zijn een uitzondering. Een aantal vrijmetselaars dragen de titel van officier, maar nemen niet deel aan de krijgsverrichtingen. Ze zijn actief in de verzorging van mens en dier of in de logistiek. Zo bevat de lijst vijf artsen, een gezondheidsofficier, een dierenarts, een schoenmaker, een directeur, een attaché en een econoom, allen verbonden aan het militair hospitaal, en een artiest. De meesten maken deel uit van het Franse, Pruisische of Nederlandse leger. Van 48 vrijmetselaars is het geboortejaar bekend. Hierbij valt op dat ze allen (behalve Benjamin Migeon, geboren in 1812) geboren zijn vóór 1800, voornamelijk in de periode 1780-1797.

\section{De beofenaars van een vrij beroep}

Vrijmetselaars die een vrij beroep uitoefenen vormen een derde groep met 70 personen. De advocaten maken met 28 vrijmetselaars de grootste subgroep uit gevolgd door de artsen (15), de apothekers (6), de notarissen (5), de deurwaarders (5), één architect, één tandarts en drie dierenartsen. De juridische beroepen (advocaat, notaris en deurwaarder) maken met 38 vrijmetselaars meer dan de helft van die groep uit $(53,5 \%)$. Hierbij moet vermeld worden dat vijf artsen en één dierenarts ingedeeld zijn bij de groep van de militairen. Voor de grote groep advocaten heb ik niet direct een verklaring gevonden. Wel zijn sommigen niet enkel advocaat. Seth Fils $\left({ }^{\circ} 1782\right)$ is naast advocaat ook nog brandewijnstoker in Groot Meirhem. Jean Constant Crocquet ( $\left.{ }^{\circ} 1786\right)$ zou ook nog industrieel zijn en bediende aan het Gouvernement. Charles Louis Leirens $\left({ }^{\circ} 1809\right)$ is ook nog bijzonder ontvanger en beheerder van onroerende goederen. Edmond Henri Willequet ( $\left.{ }^{\circ} 1825\right)$ heeft ook nog een leeropdracht aan de nijverheidsschool. Prosper Claeys ( $\left.{ }^{\circ} 1834\right)$ is ook schrijver van historische artikelen. Emile De Beil ( ${ }^{\circ}$ ?) is naast advocaat ook fabrikant. Henri Coryn ( ${ }^{\circ}$ ?) is ook nog plaatsvervangend rechter in de rechtbank van Dendermonde. 


\section{De ambtenaren}

Ook 47 ambtenaren maken deel uit van Le Septentrion. Het grootste deel situeert zich in de klassieke ambtenarij: de diverse besturen, de fiscale administratie, de politie, .... Een subgroep binnen de ambtenarij vormt de magistratuur met negen vrijmetselaars. Voor dit artikel heb ik zowel de leden van de zetelende en de staande magistratuur als de leden van de griffie in deze groep ondergebracht.

\section{Onderwijs}

Vertegenwoordigers uit het onderwijs hebben een ambtenarenstatuut. Gezien hun eigenheid werden deze in een aparte categorie van 25 vrijmetselaars ingeschaald. Ook de professoren heb ik als een subgroep afgebakend. Deze is beperkt tot de op de website 'UGentMemorialis' opgenomen professoren en de hoogleraars aan de universiteit van Luik. ${ }^{82}$ Leraars van een atheneum, muziekleraars en onderwijzers, van wie sommigen de titel professor voeren, heb ik geweerd. Slechts vier vrijmetselaars van Le Septentrion waren in de besproken periode professor aan een universiteit. Destijds waren er wel minder professoren.

\section{De kunstenaars}

Achtentwintig vrijmetselaars telt de categorie kunstenaar. De groep schilders en tekenaars omvat acht vrijmetselaars evenals de groep van de musici. Zes vrijmetselaars noemen zich 'artiest' zonder verdere definiëring; vier vrijmetselaars zijn actief in drama of als acrobaat. De aanwezigheid van de vele schilders kan ik niet verklaren. De aanwezigheid van de vele musici is te herleiden tot deelname aan de harmoniekolom. Muziek is erg belangrijk tijdens de maçonnieke zittingen. In de besproken periode werden liederen nog gezongen onder leiding van een vrijmetselaar kapelmeester, de officier-dignitaris verantwoordelijk voor de harmoniekolom. De vrijmetselaars van de harmoniekolom waren vaak 'broeders van de talenten'. Zij werden vrijgesteld van bijdragen in ruil voor hun arbeid. Ook zij behoren niet tot de hogere sociale klassen in de profane maatschappij. Het lidmaatschap van de harmoniekolom was gegeerd. In 1835 gaven velen zich op maar werd het aantal tot zes vrijmetselaars beperkt. ${ }^{83}$

De vrijmetselarij bood binnen haar geplogenheden ruim de gelegenheid voor het zingen van liederen. Dat gebeurde hoofdzakelijk tijdens het rituele banket dat

82 UGentMemorialis, geraadpleegd op 18/02/2018, http://www.ugentmemorialis.be/.

83 2.A.10/(1.0631), Registre des délibérations du conseil d'administration (1835-1873), 1835-04-10-3. 
plaats vond na het tempelritueel. Tijdens dat tempelritueel werd opvallend weinig gezongen. ${ }^{84}$ Tot 1854 onthielden de vrijmetselaars zich theoretisch van politiek in de werkplaats. Politieke agitaties, antiklerikale retoriek en onderlinge onenigheden bleken schering en inslag. $\mathrm{Zij}$ konden wel hun weg vinden in maçonnieke liedteksten. ${ }^{85}$

\section{De renteniers}

De volgende groep vormen de 28 renteniers. Vaak geven zij als beroep rentenier of particulier op, soms eigenaar. Normaal zou men verwachten dat deze groep wel een aantal verkiesbaren voor de Senaat bevat. Slechts één vrijmetselaar werd teruggevonden in die lijst. Het betreft Hyacinthe Mathot ( ${ }^{\circ}$ Fosse, 1806).

\section{De leidinggevenden}

Dertien leidinggevenden zijn vrijmetselaars van Le Septentrion. Oscar Charles Louis Alfred Prayé ( $(?)$ ) uit Doornik is weliswaar doctor in de rechten, maar is geen advocaat. De Gentenaar Charles Marie Napoléon Droesbeke ( $\left.{ }^{\circ} 1836\right)$ heeft ingenieurswetenschappen gestudeerd. Hij houdt zich bezig met openbare verkopingen. De andere elf zijn allen kapitein ter langen omvaart (9) of scheepskapitein (2). Van acht onder de kapiteins is de moedertaal gekend. Merkwaardig genoeg geven zeven op Nederlandstalig te zijn. Die groep heeft ook maar weinig binding met Gent want slechts drie van de elf leden verblijven in Gent.

\section{De werknemers}

Een aantal vrijmetselaars vormen de groep van tien werknemers. Best vertegenwoordigd met zes vrijmetselaars zijn de bedienden. De overige bekleden functies van meester metser, meester loodgieter, scheepsmeter en werktuigkundige.

\section{De 'hommes de lettres'}

De laatste groep van negen vrijmetselaars bevat zowel de journalisten als de schrijvers. Sommigen combineren beiden. Het gaat hier om vrijmetselaars wiens hoofdactiviteit bestaat in het schrijven. Hun journalistieke opdracht vervullen ze meestal

84 David Vergauwen, Maçonnieke chansons in negentiende-eeuws België (Brussel: ASP, 2017),15.

85 Vergauwen, Maçonnieke chançons, 47-57. 
bij Franstalige dagbladen zoals Le Messager de Gand. Vermeldenswaard is Willem Rogghé. Hij was bij de Vlaamstalige pers actief zoals bij Gazette van Gent en Goudmijn des Landmans. Er zijn nog advocaten en andere vrijmetselaars die als nevenactiviteit publiceerden. Zij zijn niet in die groep opgenomen.

Is er nu een vergelijking mogelijk met andere werkplaatsen? René Vermeir bracht het professionele profiel van de eerste 150 leden van La Liberté in kaart, maar La Liberté werd pas opgericht in 1866 dus na de besproken periode. Zowel de groepen als de tijdskaders zijn niet vergelijkbaar. ${ }^{86}$ Hoewel La Liberté ontstaan is uit Le Septentrion hebben beide werkplaatsen een ander profiel. Het jubileumboek naar aanleiding van het 125 -jarige bestaan van de werkplaats Marnix van Sint-Aldegonde vermeldt de sociale samenstelling enkele jaren na de oprichting in 1890. Ook hier is geen vergelijking mogelijk gezien de verschillende tijdskaders. Jacques Mertens beschrijft de sociologische samenstelling van de West-Vlaamse loge L'Amitié in de periode 1803-1833. De tijdskaders zijn niet volledig vergelijkbaar maar overlappen elkaar 22 jaar. Op 106 leden zijn er 30 ambtenaren (28,3\%), 28 ondernemers (26,4\%), 15 militairen (14,15\%), 12 magistraten (11,3\%), 9 beoefenaars van een vrij beroep (8,5\%), 9 renteniers en particulieren (8,5\%) en 3 burgemeesters $(2,8 \%) \cdot{ }^{87} \mathrm{Het}$ is duidelijk dat de sociologische samenstelling van L'Amitié afwijkt van deze van Le Septentrion. Onder de vrijmetselaars van L'Amitié maken de ambtenaren de grootste groep uit en zijn er ongeveer de helft minder ondernemers. De enige categorie die in beide werkplaatsen vergelijkbaar is, zijn de militairen.

Ook in het buitenland vond ik niet direct punten van vergelijking. ${ }^{88}$

De vraag stelt zich of bepaalde groepen in bepaalde periodes meer of minder dan het gemiddelde ingewijd werden. Drie groepen tellen meer dan $10 \%$ en zijn dan ook representatief. Het zijn de groepen van de ondernemers, de militairen en de beoefenaars van een vrij beroep. Van 296 ondernemers kennen we het jaar van ini-

\footnotetext{
Vermeir en Tyssens, Vrijmetselarij en Vooruitgang, 118.

Mertens, "De vrijmetselarij in West-Vlaanderen: een sociologische benadering," 185.

88 Eric Saunier, Révolution et sociabilité en Normandie au tournant des XVIIIe \& XIXe siècles (Rouen, Publications de l'Université de Rouen, 1998), 555. Eric Saunier heeft zeer gedegen onderzoek verricht naar de vrijmetselarij in de achttiende en negentiende eeuw in Normandië. Hij bestudeerde het profiel van 6000 vrijmetselaars in de periode 1740 tot 1830 . Hij besteedt aandacht aan de veranderende sociabiliteit. Voornamelijk in het derde en vierde hoofdstuk beschrijft hij de diversiteit tussen de vrijmetselaars. Hij hecht hierbij veel belang aan de invloed van de Franse revolutie op het wijzigende profiel van de vrijmetselaar. Uiteindelijk bestudeert hij de maçonnieke profielen in een volledige regio (Normandië, ongeveer 100 loges) en niet in een stad (Gent, één loge). Ook de tijdskaders overlappen maar enkele jaren (1811-1830); Agulhon, Pénitents et Francs-Maçons de l'ancienne Provence, 173-74. Maurice Agulhon bestudeerde gedetailleerd de sociale samenstelling van de moederloge van Marseille. Marseille en Gent zijn beiden havensteden, maar beide onderzoeken zijn totaal niet vergelijkbaar. Agulhon vertrekt in zijn studie van 1780. De tijdskaders lopen ook hier niet parallel.
} 
tiatie. Dit is ook het geval voor 50 militairen en 63 beoefenaars van een vrij beroep. De curve van de ondernemers volgt praktisch perfect de globale curve. Meer militairen worden tot 1831 relatief bekeken ingewijd dan het gemiddelde. Ik verwijs ook naar de historische context hiervoor. In de jaren 1840 wordt het militairen verboden om het lidmaatschap van een werkplaats te aanvaarden. ${ }^{89}$ Op basis hiervan kan ik besluiten dat officieren voornamelijk de eerste drie decennia na de oprichting Le Septentrion bevolkten. ${ }^{90}$ Beoefenaars van een vrij beroep hinken tot 1831 relatief bekeken achter op de globale trend. Nadien volgen zij min of meer de globale trend.

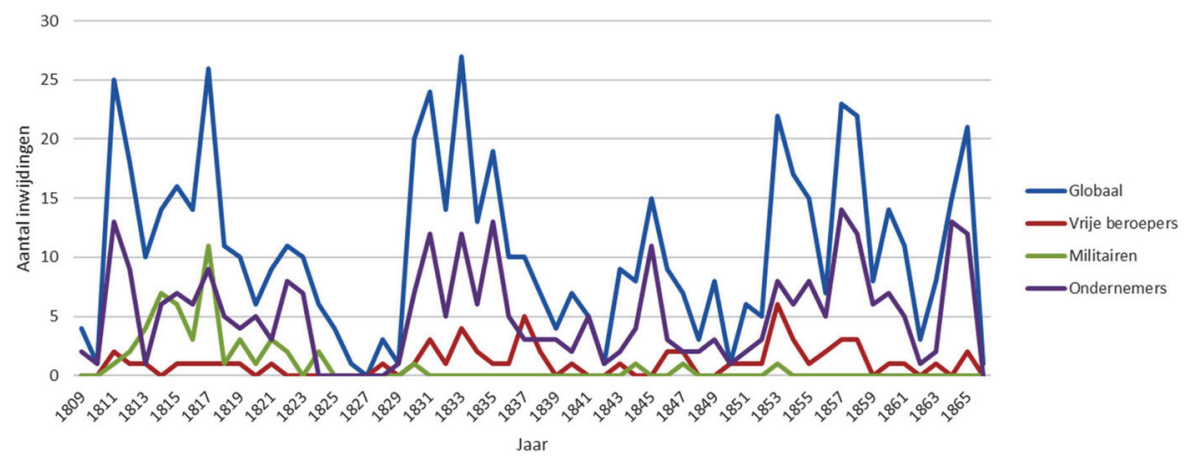

Grafiek 2: Inwijdingen per jaar globaal en voor de ondernemers, de militairen en de beoefenaars van een vrij beroep.

De analyse van de beroepen bevestigt de stelling dat eerder de hogere middenklasse lid was van Le Septentrion. De intellectuele (professoren ${ }^{91}$, hogere magistratuur) en de financiële en industriële high society van Gent (bankiers, textielbaronnen, ...) waren relatief weinig vertegenwoordigd in Le Septentrion in de besproken periode. Ook de sociale samenstelling van de werkplaatsen evolueert duidelijk. In een volgend deel ga ik dieper in op het vermogen van de vrijmetselaars.

89 Tyssens, "Van Wijsheid met Vreugd gepaard," 19.

90 Bij de Belgische strijdkrachten vormen de kapitein-commandant, de kapitein, de luitenant en de onderluitenant de groep van lagere officieren. Voor de zeemacht correspondeert dit met de graden van luitenant-terzee eerste klasse tot vaandrig-ter-zee tweede klasse.

91 Ik wens wel op te merken dat er toen beduidend minder hoogleraars waren. 


\section{Het vermogensprofiel}

Het beroepsprofiel werd hiervoor onderzocht. Een onderzoek naar het vermogensprofiel diept het beroepsprofiel uit. René Vermeir besluit in zijn onderzoek over La Liberté dat de mannen die in de 19 de eeuw deel uitmaakten van een werkplaats tot de meest gegoeden van hun tijd behoorden. ${ }^{92}$ Zou dit ook voor de vrijmetselaars van Le Septentrion het geval zijn? In de onderzochte periode bestond een systeem van cijnskiesrecht. Wie kiesgerechtigd was beschikte over een zeker vermogen. Het recht om politieke mandatarissen te verkiezen was in de $19 \mathrm{de}$ eeuw verbonden met de economische betekenis van de kiezer. Die economische betekenis werd vastgelegd aan de hand van de betaalde belastingen. ${ }^{93}$ De Schampheleire, Witte en Borné geven fortuinindicaties voor de Franse en Hollandse periode tot 1824 in de zin dat zij aanduiden of een persoon tussen 50 en 100 florijnen belasting betaalde dan wel meer dan 100 florijnen. ${ }^{94}$ Voor de periode 1830 tot 1848 bestond er voor de gemeenteraadsverkiezingen een verschillende cijns naargelang van de grootte van de lokaliteit. Zo lag de grens in Gent op 100 Belgische frank belasting. Op een bevolking van 105.117 inwoners op 31 december 1847 genereerde dit systeem 1.819 kiesgerechtigden. Voor het parlement en de provincieraad moest de burger 80 florijnen of 169 Belgische frank belasting betalen. Hieraan voldeden 1.019 respectievelijk 1.116 Gentenaars. Vanaf 1848 werd de cijns voor het gehele land uniform vastgelegd op 20 florijnen of 42,32 Belgische frank. Deze wijziging resulteerde te Gent in 3.482 kiesgerechtigden voor de gemeenteraad, 3.244 voor het parlement en 3.266 voor de provincieraad. ${ }^{95}$ Voor de Senaat creëerde de grondwetgever nog een aparte categorie van verkiesbare mannen en legde de voorwaarden voor hun verkiesbaarheid vast. ${ }^{96}$ Deze laatste voorwaarde, jaarlijks 1000 gulden belasting betalen, is een essentieel criterium voor het afbakenen van de onderzoeksgroep. De Belgische frank werd pas ingevoerd in 1832 en vanaf dan werd het equivalent van

92 Vermeir en Tyssens, Vrijmetselarij en Vooruitgang, 129.

93 Marc Reynebeau, "De kiescijnsverlaging van 1848 en de politieke ontwikkeling te Gent tot 1869," BTNGRBHC11, nr. 3 (1980): 262.

94 De Schampheleire, Witte en Borné,"Vrijmetselaars te Gent tijdens het Empire en de Hollandse periode (1804-1824)," 87.

95 Reynebeau, “De kiescijnsverlaging van 1848 en de politieke ontwikkeling te Gent tot 1869," 262-63. De verschillen tussen provincie en parlement houden verband met de naturalisatie van vreemdelingen. Voor de provincieraad volstond de kleine naturalisatie.

96 Artikel 56 Grondwet van 7 februari 1831, Belgisch Staatsblad, 7 februari 1831. De vervulling van vijf voorwaarden was vereist. 1 Belg zijn van geboorte of de Belgische nationaliteit bekomen hebben door grote naturalisatie. 2 Over alle burgerlijke en politieke rechten beschikken. 3 Gedomicilieerd zijn in België. 4 Minstens 40 jaar oud zijn. 5 In België minstens 1000 gulden belasting betalen met inbegrip van de patentbelasting. 
1000 florijnen, te weten 2116,40 Belgische frank als wisselkoers genomen. ${ }^{97}$ Deze regelgeving bleef van kracht tot de eerste herziening van de Grondwet in 1893.98 Om de cijns en dus de verkiesbaarheid te bepalen bracht de overheid vijf soorten belasting in rekening: de grondbelasting, de persoonlijke belasting, de patentbelasting, de royalties op mijnconcessies en accijnzen op tabak en dranken. ${ }^{99}$

Tot zover de theorie die nu getoetst wordt aan de onderzoeksresultaten. Qua methodiek toets ik het lidmaatschap van Le Septentrion aan de lijst van De Schampheleire, Witte en Borné die loopt tot 1824, de kiezerslijst van Gent van 15 april $1852^{100}$ en de Gentse lijst van de verkiesbaren voor de Senaat. De resultaten worden per lijst besproken. De meest democratische lijst is deze van 1852, waar de grens op 20 florijnen ligt; de meest elitaire is de lijst met verkiesbare mannen voor de Senaat, waar de grens op 1000 florijnen ligt. In de periode 1811 tot 1824 betalen vijf vrijmetselaars tussen 50 en 100 florijnen belasting en veertien vrijmetselaars betalen meer dan 100 florijnen belasting. De ledenlijst van 1823 van Le Septentrion is een momentopname en bevat 56 namen van residerende leden, van wie veertien vrijmetselaars (25\%) meer dan 50 florijnen belasting betaalden. Op de lijst van De Schampheleire, Witte en Borné staan wel de namen van 26 vrijmetselaars, lid van Les Vrais Amis en van 30 vrijmetselaars, lid van La Félicité Bienfaisante. Dit geeft een aanwijzing dat meer gefortuneerden zich aansloten bij beide andere Gentse loges. ${ }^{101}$ De tweede lijst van het onderzoek is de kiezerslijst van 1852 waarop ongeveer 3500 kiesgerechtigden vermeld staan die minstens 42,32 frank (20 florijnen) belasting betaalden. Dit cijfer correspondeert met ongeveer 3\% van de Gentse bevolking. Op basis van die kiezerslijst hadden 126 vrijmetselaars stemrecht. Die 126 vrijmetselaars zijn het resultaat van een momentopname (het jaar 1852) en van een plaatsopname (Gent). De vrijmetselaars vóór 1852 gestorven kunnen nog niet op de lijst voorkomen, net zoals vrijmetselaars die in 1852 niet de leeftijd om in te treden bereikt hadden. Alle vrijmetselaars ingewijd tijdens een pas-

97 Jean-Luc De Paepe, Massia Gruman, Ginette Kurgan-Van Hentenryk, Huguette Schoeters en Jean Stengers, Index des éligibles au Sénat: 1831-1893 (Bruxelles: Académie royale des sciences, des lettres et des beaux-arts de Belgique, 1975), 15.

98 De Paepe et al., Index des éligibles au Sénat, 15.

99 Voor een uitgebreide bespreking van de diverse belastingen verwijs ik naar De Paepe et al., Index des éligibles au Sénat, 17-28.

100 België, Gent, Stadsarchief De Zwarte Doos Reeks VIII, nr. 80: Lijst der kiezers van de Kamer der Volksvertegenwoordigers en de Senaat, 1858, 1 deel. Het stadsarchief beschikt over vier kiezerslijsten uit die periode. De oudste lijsten uit reeks VIII nr. 292 vindt het archief niet meer terug. De lijst van reeks VIII nr. 79 dateert van voor 1848 en bevat slechts 1809 namen van kiesgerechtigden. Er is ook nog een lijst van reeks VIII nr. 47, maar deze bevat de kiesgerechtigden op 16 april 1862. De keuze om te werken met een lijst van 1852 uit reeks VIII nr. 80 is ingegeven omdat deze lijst het meest representatief is.

101 Ik zou over ledenlijsten van beide werkplaatsen in die periode moeten beschikken om te kunnen berekenen of dit procentueel ook het geval is. Dit viel buiten het onderwerp van mijn onderzoek. 
sage aan Gent zullen niet voorkomen op de lijst. Dit geldt ook voor alle niet-residerende vrijmetselaars. Tabel 4 geeft een goed beeld van het verschil in vermogen tussen de leden. De renteniers betalen gemiddeld het meest belastingen gevolgd door de ondernemers. De mensen met een vrij beroep zitten net onder het gemiddelde; de ambtenaren, de militairen en de kunstenaars zijn naar vermogen minder bedeeld. Degene die het meest belasting betaalde is niet noodzakelijk de meest vermogende. Het bedrag aan betaalde belastingen is een amalgaam van grondbelasting, personenbelasting, patentbelasting en een belasting op gedistilleerde dranken (Débit de Boissons Distillées). Belastingen werden per gemeente betaald en daarom maakt de kieslijst een onderscheid tussen de belastingen betaald in de gemeente waar men gedomicilieerd is en belastingen in andere gemeenten betaald. Om politieke redenen woog de grondbelasting het zwaarst door. De gezagsgetrouwe, koningsgezinde adel bezat veel grond en haalde snel de grens om kiesgerechtigd te zijn. Dit verklaart het hoge bedrag dat renteniers betalen. ${ }^{102}$ Voor het jaar 1853 (5853) is een ledenlijst bewaard in Den Haag met hierop een onderscheid naargelang een vrijmetselaar al dan niet het residerend statuut had. Volgens die lijst zijn er 69 vrijmetselaars lid van Le Septentrion, waarvan er 23 niet in Gent resideren en dus niet op de kieslijst kunnen staan. ${ }^{103}$ Analyse van de 46 Gentse leden leert dat twaalf onder hen in 1853 lid waren van Le Septentrion en geen 20 florijnen belastingen betaalden (26\%). Hieronder bevinden zich Hippolyte de Matthys die nog student is, de schrijver Charles Huysentruyt, maar ook Benoit Stevin, uitgever van de orangistische krant Le Messager de Gand in 1831, die ten gevolge van de Belgische repressie naar Parijs gevlucht was. Twee advocaten, Edmond Willequet en Gustave Poirier, betalen de belasting niet evenals de koopmannen Charles De Ketelaere, August De Bruycker, Leonard Duyck en Charles GillisPulinx. Waarschijnlijk gaat het hier om 'kleine zelfstandigen' net zoals Jean-Baptiste Lemaire, die hotelier als beroep opgeeft. Louis Lefebvre en Victor Van Zandvoorde vervolledigen de lijst. Hieruit blijkt duidelijk dat het merendeel over een behoorlijk vermogen beschikt. De derde lijst is gebaseerd op de diverse bestuursmemorialen van de provincie Oost-Vlaanderen. Slechts 444 Gentse burgers zijn verkiesbaar voor de Senaat in de periode 1831-1893. ${ }^{104}$ Van alle vrijmetselaars zijn er tien vrijmetselaars die figureren op die lijst van verkiesbaren van de Senaat (de superrijken) voor de periode 1831-1866. Onder hen zijn er zeven ondernemers. Ik

\footnotetext{
102 Voor een uitgebreide bespreking van de diverse belastingen verwijs ik naar De Paepe et al., Index des éligibles au Sénat, 17-28.

103 Liste des Officiers-dignitaires de la R(espectable) L(oge) le Septentrion à l'O(rient) de Gand, Année maçonnique 5853-5854, s.l., $1854,28 \mathrm{~cm}$., 2.GON-B, coll. Ledenlijsten in $4^{\circ}$.

104 België, Gent, Provinciaal Archief, Bestuursmemoriaal van de Provincie.
} 
kan dan ook besluiten na analyse van de drie lijsten dat op basis van vermogen niet de superrijken en weinig kleine zelfstandigen deel uitmaakten van Le Septentrion, maar wel de betere middenklasse en de hogere klasse. Mijn conclusie is volledig in overeenstemming met de bevindingen van René Vermeir.

Tabel 4: Aantal vrijmetselaars van Le Septentrion met kiesrecht ingedeeld per beroepscategorie.

\begin{tabular}{|l|c|c|}
\hline \multicolumn{1}{|c|}{ Beroepsklasse } & Aantal & Betaalde belastingen in 1852 \\
\hline Ambtenaar & 14 & 211,71 frank \\
\hline Kunstenaar & 2 & 93,05 frank \\
\hline Militair & 4 & 129,70 frank \\
\hline Ondernemer & 78 & 243,20 frank \\
\hline Rentenier & 6 & 337,65 frank \\
\hline Vrij beroep & 20 & 212,76 frank \\
\hline Werknemer & 1 & 266,41 frank \\
\hline Totaal & 125 & 233,49 frank \\
\hline
\end{tabular}

\section{Politiek engagement}

Een analyse van de politieke activiteiten van de 736 leden van Le Septentrion gaat ons een nog beter beeld geven van hun politiek engagement. De politieke activiteit van de leden werd afgemeten aan de hand van de politieke mandaten die zij vervulden. Die mandaten zijn in vier klassen onderverdeeld: mandaten op gemeentelijk niveau, mandaten op provinciaal niveau, verkozenen in de Kamer van Volksvertegenwoordigers en in de Senaat en ten slotte uitvoerende mandaten zoals burgemeester ( 5 waaronder Adegem, Zaffelaere en Munte) en schepen (9). Sommige vrijmetselaars vervullen meerdere mandaten en komen dus in meerdere klassen voor. Andere vrijmetselaars cumuleren politieke functies of vervullen meerdere mandaten gespreid in de tijd. Tenslotte werd ook nagegaan hoeveel vrijmetselaars aanwezig waren bij de stichting van de Liberale Partij te Brussel. Het boek van Kathleen Devolder heeft gediend om de lijst samen te stellen. ${ }^{105}$ Enkel met de verkozenen en niet met de kandidaten is rekening gehouden. Telkens werd nagegaan in welke mate een verkozene nog een andere functie bekleedde. De getallen tussen haakjes verwijzen hiernaar. Zo betekent 38 (7 P, 2 N, 11 U, 3 LP) dat achtendertig gemeenteraadsleden in hun politieke loopbaan ook nog zeven keer provincieraadslid waren, twee nationale mandaten vervulden, elf uitvoerende mandaten bekleed-

105 Devolder, Gij die door 't volk gekozen zijt ..., 233-454. 
den en dat drie onder hen aanwezig waren bij de stichting van de Liberale Partij. Volgens tabel 5 hebben de vrijmetselaars van Le Septentrion 73 functies bekleed gespreid over de vijf categorieën. Onder hen hebben er 38 of $52 \%$ een mandaat als gemeenteraadslid opgenomen. Van de elf leden met een mandaat als provincieraadslid waren er zeven ook lid of lid geweest van de gemeenteraad. Van de veertien vrijmetselaars met een uitvoerend mandaat hebben er elf ooit in de gemeenteraad gezeteld, vijf in de provincie en twee in het parlement. De cijfers tonen duidelijk een sterke verankering aan met de lokale politiek onder de vorm van mandaten opgenomen als gemeenteraadsleden, schepenen en burgemeesters.

Tabel 5: Overzicht van de politieke activiteiten van de leden van Le Septentrion in de periode 1811-1866.

\begin{tabular}{|l|l|r|}
\hline \multicolumn{1}{|c|}{ Politiek engagement } & \multicolumn{1}{c|}{ Aantal } & Procent \\
\hline Gemeenteraadslid & $38(7 \mathrm{P}, 2 \mathrm{~N}, 11 \mathrm{U}, 3 \mathrm{LP})$ & $52,05 \%$ \\
\hline Provincieraadslid & $11(7 \mathrm{G}, 2 \mathrm{~N}, 5 \mathrm{U}, 1 \mathrm{LP})$ & $15,07 \%$ \\
\hline Nationaal mandataris & $5(2 \mathrm{G}, 2 \mathrm{P}, 2 \mathrm{U}, 1 \mathrm{LP})$ & $6,85 \%$ \\
\hline Uitvoerend mandaat & $14(11 \mathrm{G}, 5 \mathrm{P}, 2 \mathrm{~N})$ & $19,18 \%$ \\
\hline Stichter Liberale Partij & $5(3 \mathrm{G}, 1 \mathrm{P}, 1 \mathrm{~N})$ & $6,85 \%$ \\
\hline Totaal & 73 & $100,00 \%$ \\
\hline
\end{tabular}

Op 18 juni 1846 wordt in Brussel de Liberale Partij boven de doopvont gehouden. Gezien de verwantschap op confessioneel vlak verwacht men een zekere aanwezigheid van de leden van Le Septentrion op dit congres. De lijst met de stichtende leden van de Liberale Partij bevat 348 namen. ${ }^{106}$ De stichtende leden komen van over het hele land met een grote nadruk op leden uit Brussel. Consultatie van die lijst leert dat twaalf Gentenaars aanwezig waren op het stichtingscongres. Hiervan zijn vijf vrijmetselaars lid van Le Septentrion. ${ }^{107}$ In het zog van de liberale partij werd een Gentse pendant opgericht: de Liberale Associatie / Association Libérale Constitutionelle. ${ }^{108}$ Deze heeft tot doel op een legale wijze de principes van de grondwet te verdedigen, te komen tot een goede vertegenwoordiging in de kamers, de provincieraad en in de gemeenteraad en te zorgen dat er bekwame mensen zete-

\footnotetext{
106 Lijst met de stichtende leden van de Liberale Partij op 14 juni 1846, geraadpleegd op 18/02/2018, http:// www.liberaalarchief.be/archief5-1846bis.html.

107 Hippolyte Metdepenningen was niet aanwezig maar verontschuldigd. Hij werd vertegenwoordigd door de advocaat Charles Antheunis. Volgende aanwezigen zijn geen lid van Le Septentrion: Delwarde, advocaat, Delehaye, vertegenwoordiger, Henry-Vispoel, négociant, Vandevelde, conseiller à la cour d'appel en Vergauwen, sénateur.

108 Joumal des Flandres, 11.6.1848
} 
len. ${ }^{109}$ Op 26 juni 1848 stelt een comité statuten op voor deze vereniging in oprichting. ${ }^{110}$ Onder de zeventien stichters bevindt zich op dat moment slechts één broeder van Le Septentrion namelijk Julius Vuylsteke. ${ }^{111}$ Hippolyte Metdepenningen wordt wel bij de eigenlijke oprichting tot ondervoorzitter benoemd.

De studies van Kathleen Devolder en Marc Reynebeau geven aan dat er in 1848 voor de gemeenteraad in Gent 31 mandaten ingevuld moesten worden en dat er 3.482 kiesgerechtigden waren. ${ }^{112}$ Dit betekent dat er één mandaat per 112 kiesgerechtigden voorzien werd. In dat jaar werden ook gemeentekiezingen gehouden op 22 en 23 augustus 1848. ${ }^{113}$ Acht verkozen gemeenteraadsleden zijn aangesloten bij Le Septentrion namelijk Edouard van Pottelsberghe, Charles Van Duyn, Edouard Neyt, Edouard Jacquemyns, Napoléon de Pauw, Auguste Van Lokeren, Louis Blommaert en Norbert-Joseph Claus-Van Aken. ${ }^{114}$ Het college van burgemeester en schepenen draagt ook de signatuur van Le Septentrion. De Kerckhove de Denterghem bleef burgemeester. Van de vijf schepenen waren er drie vrijmetselaars van Le Septentrion: van Pottelsberghe, De Pauw en Van Lookeren. ${ }^{115}$ Samenvattend blijkt uit de politieke aanwezigheid de intense verbondenheid van Le Septentrion met de Liberale Partij en een meer dan gemiddeld politiek engagement van de vrijmetselaars op lokaal vlak. In een volgende paragraaf bekijk ik de maatschappelijke positionering van de vrijmetselaars van Le Septentrion.

\section{Maatschappelijke positionering}

Vrijmetselaars leven ook in een profane maatschappij. Zij maken deel uit van het sociale weefsel en nemen deel aan het verenigingsleven. Niet alleen in de loges heerste een soort sociabiliteit, de behoefte om met gelijkgestemden activiteiten te ontplooien. Dit concretiseerde zich in de oprichting van verenigingen, bij voorkeur voor mannen en in de steden. Sociabiliteit gaat trouwens hand in hand met de uit-

\footnotetext{
109 Règlement pour l'Association libérale constitutionelle de Gand, Artikel 2.

110 Devolder, Gij die door 't volk gekozen zijt, 114. Ze nam het politiek programma van de Brusselse Association Libérale over. In het voorlopig reglement dat op 8 juli 1848 uitgegeven werd, werd het grondwettelijk karakter van de Association Libérale Constitutionnelle sterk benadrukt (art. 1). Het lidmaatschap van de vereniging werd voorbehouden aan kiesgerechtigden (art. 2) die jaarlijks 5 frank lidgeld betaalden (art. 9). De Associatie zou haar activiteiten beperken tot het controleren van de kiezerslijsten (art. 10), en het voordragen van kandidatenlijsten bij verkiezingen (art. 11 en 12).

111 Règlement provisoire de la Société Libérale-Constituitionelle de l'arrondissement de Gand, artikel 17.

112 Kathleen Devolder, Gij die door 't volk gekozen zijt, 510; Marc Reynebeau, "De kiescijnsverlaging van 1848 en de politieke ontwikkeling te Gent tot 1869," 262-63.

113 Door overlijden waren er tussentijdse verkiezingen op 27 november 1849 waarbij drie gemeenteraadsleden verkozen werden. Hierbij 'verloor' Le Septentrion één mandaat. Norbert-Joseph Claus en Edouard Neyt verdwenen uit de gemeenteraad en Charles Antheunis werd gekozen.

114 Devolder, Gij die door 't volk gekozen zijt, 510.

115 Standaert, Politiek en pers, 140.
} 
bouw van het staatsburgerschap. Burgers hadden genootschappen en schouwburgen. Arbeiders hadden cafés en clublokalen. Deze vormen van sociabiliteit ontstonden in de tweede helft van de $18 \mathrm{de}$ eeuw. Rond 1830 waren er in Gent een vijftigtal sociaal-culturele verenigingen. Typisch voor de burgerlijke genootschappen waren hun beslotenheid en hun privékarakter. Na 1830 werden dan naar Frans model 'cercles' opgericht. Die genootschappen probeerden de burger sociaal en cultureel te vormen door een algemeen ideaal te promoten. ${ }^{116}$ Voor de meeste vrijmetselaars primeerde het gezelligheidsaspect op het filosofische project en op het politieke engagement. ${ }^{117} \mathrm{Na} 1830$ zou die sociabiliteit een voedingsbodem vormen voor politieke mobilisatie. De Gentse werkplaatsen en de andere genootschappen creëerden eerst een draagvlak voor het orangisme en pas nadien reageerden ze tegen de clerus. ${ }^{118}$

In deze paragraaf wordt gepeild naar de aanwezigheid van vrijmetselaars in enkele liberaal getinte organisaties zoals de Société Huet, La Concorde, het Willemsfonds en het Van Crombrugghe's Genootschap. In de 19de eeuw waren de salons, geleid door dames, over hun hoogtepunt en ontstonden clubs voor heren. In Gent werd op 8 januari 1809 'Le Cercle La Concorde' opgericht. De leden maakten deel uit van de toenmalige stedelijke elite. Vandaag omschrijft de website van La Concorde het ledenbestand als volgt. "... en un mot, l'aristocratie de la naissance, de la fortune, du savoir et du talent s'y donnent pour ainsi dire la main." ${ }^{119}$ La Concorde is sinds haar ontstaan een 'vermakelijkheidsgenootschap'. Zij ambieert geen publieke rol, zelfs als ze gedurende bepaalde periodes van haar bestaan actief deelgenomen heeft aan het politieke leven van de stad. ${ }^{120}$ De septemberrevolutie van 1830 makkte van La Concorde een bastion van waaruit de orangisten hun strijd voor het herstel van Groot-Nederland voerden. Onder Charles d'Hane Steenhuyse, voorzitter van La Concorde na 1842 en lid van Le Septentrion, kregen het traditionele clubleven en ontspanning weer alle aandacht. ${ }^{121}$ Hippolyte Mettepenningen was de voorzitter van 1858 tot zijn overlijden in $1881 .{ }^{122}$ Een vergelijking tussen beide ledenlijsten leert dat 97 vrijmetselaars van beide genootschappen lid

\footnotetext{
116 Verbruggen, “Het verenigingsleven en de publieke ruimte 1815-1830," 108-09.

117 Jeffrey Tyssens, In vrijheid verbonden. Studies over Belgische vrijmetselaars en hun maatschappijproject in de 19de eeuw (Gent: Liberaal Archief, 2009), 18.

118 Verbruggen, "Het verenigingsleven en de publieke ruimte 1815-1830," 110-11.

119 Website La Concorde de Gand, geraadpleegd op 23/2/2017, http://www.concordegand.be/\#histoire.

120 Yves De Clercq, Cercle Royal La Concorde 1809 - 2009 (Tournai: Imprimerie Lesaffre, 2009), 9. Belangrijk zijn de eerste twee delen (bladzijde 125 tot 166) van hoofdstuk III: 1830-1904: La Concorde au centre de la vie sociale, L'indépendance de la Belgique et l'Orangisme à la Concorde (1830-1841) en La Belgique et le Libéralisme à la Concorde (1841-1875).

121 D'Hondt, Van Andriesschool tot Zondernaamstraat, 12-13.

122 De Clercq, Cercle Royal La Concorde 1809 - 2009, 165.
} 
waren. Ook hier vormen de ondernemers de grootste groep (53 vrijmetselaars $54,6 \%$ ), gevolgd door de beoefenaars van een vrij beroep (22 vrijmetselaars $22,7 \%$ ), de ambtenaren ( 8 vrijmetselaars $-8,3 \%$ ) en de renteniers ( 6 vrijmetselaars $-6.2 \%)$ en twee vrijmetselaars uit het onderwijs (2\%), twee journalisten (2\%) en één militair, één werknemer en één kunstenaar (elk 1\%). La Concorde en Le Septentrion worden vaak samen in één adem genoemd. Als dit juist is dan zouden meer dan 97 burgers op 736 leden die Le Septentrion tussen 1811 en 1866 telde een gemeenschappelijk lidmaatschap gehad hebben. Er zijn duidelijk banden, maar er werd verwacht dat deze intenser zouden zijn.

De Société Huet was een progressieve denktank 'avant la lettre', genoemd naar de uit Frankrijk afkomstige hoogleraar filosofie en socialistische denker François Huet. Ze werd opgericht op 13 juni 1846. Het voornaamste doel van de vereniging was de studie van actuele, filosofische, politieke en sociale problemen. Huet legde de nadruk op een pacifistisch geloof in vooruitgang en sociale bewogenheid. Daarom staat de Société Huet bekend als één van de eerste sociaal liberale verenigingen. Deze progressieve vereniging propageerde veralgemening van basisonderwijs, algemeen stemrecht, radicale scheiding van kerk en staat, verbetering van het lot van de arbeidersbevolking en het invoeren van een progressieve belasting. Huet zelf omschreef zijn ideeëngoed als sociaal liberalisme. De Société Huet gaf het Nederlandstalige tijdschrift De Broedermin (1848-1859) uit. Hij beïnvloedde andere progressieve sociaalliberalen zoals Gustave Callier en Jacob Heremans, beiden later schepen van onderwijs in Gent, François Laurent, Julius Vuylsteke en Paul Fredericq. ${ }^{123}$ De Société Huet bestond uit een vijftiental actieve leden. Drie onder hen (Leirens Charles, Stecher Auguste Jean, Waelbroeck Charles) maakten deel uit van Le Septentrion in de periode 1848-1866. Andere volgelingen van Huet, die echter geen lid waren van Le Septentrion, zullen later eerder kiezen voor de progressieve werkplaats La Liberté.

Een derde genootschap dat de aandacht verdient, is het Willemsfonds ${ }^{124}$. Dit Vlaams cultuurfonds werd opgericht in 1851. Aanvankelijk was het ideologisch neutraal, maar het beoogde wel de erkenning en verdediging van het Nederlands als cultuurtaal en officiële voertaal in Vlaanderen. Vanaf 1862 kozen de leden bij het aantreden van Julius Vuylsteke als secretaris voor een liberaal-vrijzinnig flamin-

123 E.C. Coppens, "La Société Huet: tussen revolutie en reactie" Handelingen der Maatschappij voor Geschiedenis en Oudheidkunde te Gent (Gent: Maatschappij voor geschiedenis en oudheidkunde, 1972), 131-51; D'Hondt, Van Andriesschool tot Zondernaamstraat, 27-8; UGentMemorialis, geraadpleegd op 19 februari 2018, http://www.ugentmemorie.be/personen/huet-francois-1814-1869.

124 Bots, Marcel, Etienne De Cuyper, Ada Deprez en Harry van Velthoven, Het Willemsfonds van 1851 tot 1914. (Gent: Provinciebestuur Oost-Vlaanderen, 1993), 11-36; D’Hondt, Van Andriesschool tot Zondernaamstraat, 67-9. 
gantisme. Het Willemsfonds werd actief ondersteund door de loges. ${ }^{125}$ De oudste Gentse ledenlijst van het Willemsfonds dateert van $1868 .{ }^{126}$ Op basis van die lijst kon vastgesteld worden dat in de periode 1851-1866 zevenenveertig vrijmetselaars lid waren van de Gentse afdeling van het Willemsfonds. Onder hen waren er slechts twee kunstenaars, twee journalisten, twee vrijmetselaars uit het onderwijs en vier ambtenaren, maar wel éénentwintig ondernemers en twaalf beoefenaars van een vrij beroep.

Tenslotte kijken we naar de aanwezigheid van vrijmetselaars in het Van Crombrugghe's Genootschap. ${ }^{127}$ Onderwijzers en oud-leerlingen van het stedelijk onderwijs hielden op 18 oktober 1857 dit genootschap boven de doopvont. De insteek was zowel filantropisch als educatief. De vereniging was gematigd vrijzinnig en Vlaamsgezind-liberaal. Zij hield emancipatorische acties zoals de strijd voor de leerplicht en voor het algemeen stemrecht. De leden waren in hoofdzaak afkomstig uit de lagere en de middenklassen. De registers met ledenlijsten zijn met de hand geschreven en onzorgvuldig bijgehouden. Vaak corresponderen namen wel met deze van vrijmetselaars van Le Septentrion, maar wordt geen voornaam vermeld of enkel een eerste letter. De ledenlijst van 1858 tot 1860 werd geconsulteerd. ${ }^{128}$ Met voorbehoud van de juistheid van mijn onderzoeksresultaten zijn vijftien vrijmetselaars in de periode 1858-1860 lid van dit genootschap.

Uit voorgaande analyse van het Gentse verenigingsleven blijkt dat de vrijmetselaars ook aan activiteiten in de profane wereld actief deelnamen. In absolute cijfers is de participatie in het vermakelijkheidsgenootschap La Concorde het grootst. De participatie in het Vlaamsgezinde Willemsfonds wijst erop dat de vrijmetselarij zich zeker niet negatief opstelde tegenover de Vlaamse zaak en de Vlaamse taal. De kleinere participatie in het eveneens Vlaamsgezinde Van Crombrugghe's Genootschap wijst eerder op de verschillende sociale samenstelling tussen de leden van het genootschap (lagere en middenklasse) en de leden van Le Septentrion (de hogere middenklasse). Société Huet was in leden beperkt, maar heeft de verdienste een aantal prominente vrijmetselaars, van wie sommigen lid van Le Septentrion, te hebben gestimuleerd in de richting van het sociaalliberalisme.

125 Els Witte, "La Franc-maçonnerie belge face au mouvement flamand du XIX siècle," in Visages de la FrancMaçonnerie belge du xviiie au xxe siècle, eds. Hasquin Hervé (Brussel: Editions ULB, 1983), 253.

126 België, Gent, Liberaal archief, Ledenlijsten Willemsfonds.

127 D'Hondt, Van Andriesschool tot Zondernaamstraat, 114-15. Dominique Verkinderen, Het Van Crombrugghe's Genootschap van 1857-1875 (Gent: Liberaal Archief,1988), 48 en 52.

128 Ledenlijsten Van Crombrugghe's Genootschap (Liberaal Archief). 


\section{Le Septentrion en de 18de-eeuwse vrijmetselarij}

Ik ben nagegaan of de leden van Le Septentrion banden hadden met vrijmetselaars uit de 18de eeuw. Guy Schrans heeft de vrijmetselaars uit die periode in kaart gebracht. ${ }^{129}$ Indirecte vaststellingen van Schrans bevestigen de aanwezigheid van militaire loges, verbonden aan diverse regimenten, in het Gentse actief vanaf 1745.130 Het jaar 1786 was een sleuteljaar voor de vrijmetselarij in de Oostenrijkse Nederlanden. De Habsburgse keizer Jozef II was aan de macht en in het kader van zijn hervormingen pakte hij ook de vrijmetselarij aan. Een Keizerlijk Decreet van 9 januari 1786 beperkte de maçonnieke activiteit tot één werkplaats per provincie in elke provinciehoofdplaats. De Declaratie van 15 mei 1786 nam alle twijfel weg en beperkte het aantal loges tot drie, alle in Brussel gevestigd. ${ }^{131}$ Van de 736 maçons uit de besproken periode zijn er veertien, die ofwel vrijmetselaar waren vóór 1786 ofwel van wie een familielid toen vrijmetselaar was. Men moet indachtig zijn dat tussen de Declaratie van Jozef II in 1786 en de stichting van Le Septentrion in 1811 een periode van 25 jaar ligt. Het opnieuw opnemen van het broederschap na 25 jaar was uiteraard niet evident. Enkel Jozef d'Hane de Stuyvenberghe was gewezen grootmeester van de Grootloge van Mons en erelid van Le Septentrion sinds 19 september 1818. Geen enkele vrijmetselaar van vóór 1786 was gewoon lid van Le Septentrion. Rekening houdend dat ook de familiebanden onderzocht werden, kan ik moeilijk poneren dat een maçonniek lidmaatschap automatisch van vader op zoon, grootvader op kleinzoon of oom op neef doorgegeven werd van de 18de naar de $19 \mathrm{de}$ eeuw voor wat betreft Le Septentrion. De beslissing van 1786 heeft duidelijk voor een cesuur gezorgd. ${ }^{132}$

\section{Profiel van de leden die naar La Liberté uitzwermen}

Binnen dit prosopografisch onderzoek leek het mij angewezen het profiel te bepalen van de leden van Le Septentrion die in 1866 de werkplaats verlaten om de loge La Liberté te stichten. Van de ongeveer 60 leden is het beroep van 54 onder hen bekend. De vrijmetselaars d'Akessian, de Segueira en d'Ancla zijn nog student, maar geven geen studierichting op. Tabel 6 vergelijkt het beroepsprofiel van de vrijmetselaars die Le Septentrion trouw bleven, met dit van de vrijmetselaars die uitzwermden. Procentueel maken $20 \%$ mensen meer met een vrij beroep hun over-

129 Guy Schrans, Vrijmetselaars te Gent in de XVIIIde eeuw. 2e vermeerd. druk. Gent: Liberaal Archief, 2009.

130 Schrans, Vrijmetselaars te Gent, 1.

131 Tyssens, "Van Wijsheid met Vreugd gepaard,"15.

132 Theoretisch is het mogelijk dat dit wel het geval was in de werkplaatsen Les Vrais Amis of La Félicité Bienfaisante, doch dit onderzoek viel buiten mijn masterscriptie. 
stap alsook dubbel zoveel ambtenaren. Maar minder ondernemers maken de overstap. Geen militairen noch kunstenaars zwermen uit naar La Liberté. De grote aanwezigheid van militairen kan beperkt worden tot de eerste drie decennia na de oprichting en is dus te verwachten. Het jaar van initiatie in Le Septentrion is voor 55 van de 60 vrijmetselaars bekend. Meer dan de helft (29 / 52,7\%) is na 1860 opgenomen, terwijl 43,6\% (24 vrijmetselaars) tussen 1851 en 1859. Hieruit leid ik af dat voornamelijk recent opgenomen vrijmetselaars de overstap naar La Liberté maken. De gemiddelde leeftijd van intrede in Le Septentrion is 31,09 jaar, wat vergelijkbaar is met de gemiddelde intredeleeftijd in La Liberté. Analyse van het verenigingsleven leert dat negentien (32\%) van de 60 vrijmetselaars lid waren van het Willemsfonds. Slechts 20\% van degenen die in Le Septentrion bleven (15 op 75) was lid van het Willemsfonds. In het COD en in de Concorde is de situatie omgekeerd. La Liberté verwelkomt zestien leden van La Concorde (27\%) tegenover 24 leden (32\%) die Le Septentrion trouw bleven. De aanwezigheid in de COD vertoont een analoge tendens: $30 \%$ uitzwermers maken deel uit van het COD tegenover $36 \%$ blijvers. Op de kieslijst van 1854 figureren 36\% van de vrijmetselaars (27 op 75), terwijl $10 \%$ van de vrijmetselaars die overstapten, op die kieslijst staan.

\begin{tabular}{|l|c|c|c|c|}
\hline \multicolumn{1}{|c|}{ Beroepscategorie } & Le Septentrion & Percentage & La Liberté & Percentage \\
\hline Ambtenaar & 3 & $4,17 \%$ & 5 & $9,26 \%$ \\
\hline Journalist Schrijver & 2 & $2,78 \%$ & 1 & $1,85 \%$ \\
\hline Kunstenaar & 1 & $1,39 \%$ & 0 & $0,00 \%$ \\
\hline Leidinggevende & 0 & $0,00 \%$ & 1 & $1,85 \%$ \\
\hline Militair & 0 & $0,00 \%$ & 0 & $0,00 \%$ \\
\hline Ondernemer & 44 & $61,00 \%$ & 31 & $57,41 \%$ \\
\hline Onderwijs & 3 & $4,17 \%$ & 2 & $3,70 \%$ \\
\hline Rentenier & 5 & $6,94 \%$ & 1 & $1,85 \%$ \\
\hline Vrij beroep & 13 & $18,06 \%$ & 12 & $22,22 \%$ \\
\hline Werknemer & 1 & $1,39 \%$ & 1 & $1,85 \%$ \\
\hline Totaal & 72 & $100,00 \%$ & 54 & $100,00 \%$ \\
\hline
\end{tabular}

\section{Besluit}

Uit de voorgaande paragrafen komt zowel een repertorium van 736 namen als een profiel van de vrijmetselaars van Le Septentrion naar voren. Het repertorium staat niet in directe relatie met het aantal actieve vrijmetselaars, die de zittingen regelmatig bijwoonden. Daarvoor werden te veel passanten geïnitieerd. Ongeveer $20 \%$ van 
de vrijmetselaars had het statuut van niet-residerende vrijmetselaar. $\mathrm{Zij}$ woonden de zittingen meestal niet bij, omdat ze te ver van Gent woonden. De aanwezigheid bedroeg gemiddeld slechts $25,77 \%$. Ongeveer de helft van de vrijmetselaars werd in Gent geboren, terwijl een kleine $80 \%$ bij zijn inwijding in Gent gedomicilieerd was. Dat $16,7 \%$ van de vrijmetselaars in het buitenland geboren werd, is voornamelijk te herleiden tot de aanwezigheid van militairen in Le Septentrion. Analyse van geboorte- en sterftedata leert dat de vrijmetselaars gemiddeld 61,20 jaar oud werden. Het aantal inwijdingen per jaar vertoont drie piekmomenten: direct na de oprichting, de eerste vijf jaar van het veneralaat van Metdepenningen en in de periode vanaf 1853 . De sociologische samenstelling veranderde doorheen de besproken periode. De eerste decennia werden bijvoorbeeld veel militairen ingewijd. Taalproblematiek stelde zich niet in Le Septentrion. De voertaal was duidelijk het Frans met respect voor de vrijmetselaars die de taal van Molière minder goed beheersten. Individueel waren sommige leden voorvechters van de Vlaamse zaak, maar de werkplaats zelf hield zich in de besproken periode op de achtergrond. Uiteindelijk waren toch 47 vrijmetselaars lid van het Willemsfonds in de besproken periode. Confessioneel geeft 71,8\% aan dat ze tot de rooms-katholieke kerk behoort, ook na het bisschoppelijke verbod van 1838. Beroepshalve zijn de helft van de vrijmetselaars ondernemers. De militairen en de beoefenaars van een vrij beroep vertegenwoordigen elk ongeveer $11 \%$. Ambtenaren sluiten hierop aan met 7,51\%. Renteniers en kunstenaars zijn met ongeveer $5 \%$ relatief goed vertegenwoordigd. Voor de groep van de kunstenaars houdt dit deels verband met hun aanwezigheid op de harmoniekolom. Ongeveer $4 \%$ van de vrijmetselaars is actief in het onderwijs. Gebaseerd op de kiezerslijsten blijkt duidelijk dat de leden van Le Septentrion minstens tot de hogere middenklasse behoren, maar bijna niet tot de kleine groep van superrijken die meer dan 1000 gulden belastingen betalen. Ook in Le Septentrion betalen de vrijmetselaars met veel grond en eigendom de meeste belastingen, gevolgd door de groep van de ondernemers. Het relatief beperkt lidmaatschap van vrijmetselaars van Le Septentrion in de Kamer van Koophandel en de Cercle Commercial et Industriel, beide tempels van de hoogste burgerij, bevestigt de stelling dat eerder de hogere middenklasse en de hogere klasse lid was van Le Septentrion. Het politieke engagement van de vrijmetselaars is meer dan gemiddeld en uiteraard gericht op de Liberale Partij. De vrijmetselaars van Le Septentrion blijken goed ingebed te zijn in het verenigingsleven van het Gent van de 19de eeuw. Zij maken in meer of mindere mate deel uit van La Concorde, het Willemsfonds, het Van Crombrugghe's Genootschap en zelfs van de progressieve kring Société Huet. Een minimaal aantal vrijmetselaars tenslotte heeft banden met vrijmetselaars uit de 18 de eeuw. 